\title{
Impact of the variability in vertical separation between biomass burning aerosols and marine stratocumulus on cloud microphysical properties over the Southeast Atlantic
}

\author{
Siddhant Gupta ${ }^{1,2}$, Greg M. McFarquhar ${ }^{1,2}$, Joseph R. O'Brien ${ }^{3}$, David J. Delene ${ }^{3}$, Michael R. Poellot ${ }^{3}$, \\ Amie Dobracki $^{4}$, James R. Podolske ${ }^{5}$, Jens Redemann ${ }^{2}$, Samuel E. LeBlanc ${ }^{5,6}$, Michal Segal-Rozenhaimer ${ }^{5,6,7}$, and \\ Kristina Pistone ${ }^{5,6}$ \\ ${ }^{1}$ Cooperative Institute for Mesoscale Meteorological Studies, University of Oklahoma, Norman, OK, USA \\ ${ }^{2}$ School of Meteorology, University of Oklahoma, Norman, OK, USA \\ ${ }^{3}$ Department of Atmospheric Sciences, University of North Dakota, Grand Forks, ND, USA \\ ${ }^{4}$ Department of Atmospheric Sciences, Rosenstiel School of Marine and Atmospheric Science, \\ University of Miami, Miami, FL, USA \\ ${ }^{5}$ NASA Ames Research Center, Moffett Field, CA, USA \\ ${ }^{6}$ Bay Area Environmental Research Institute, Moffett Field, CA, USA \\ ${ }^{7}$ Department of Geophysics and Planetary Sciences, Porter School of Environmental and Earth Sciences, \\ Tel Aviv University, Tel Aviv, Israel
}

Correspondence: Siddhant Gupta (sid@ou.edu)

Received: 5 October 2020 - Discussion started: 27 October 2020

Revised: 12 February 2021 - Accepted: 16 February 2021 - Published: 25 March 2021

\begin{abstract}
Marine stratocumulus cloud properties over the Southeast Atlantic Ocean are impacted by contact between above-cloud biomass burning aerosols and cloud tops. Different vertical separations ( 0 to $2000 \mathrm{~m}$ ) between the aerosol layer and cloud tops were observed on six research flights in September 2016 during the NASA ObseRvations of Aerosols above CLouds and their intEractionS (ORACLES) field campaign. There were 30 contact profiles, where an aerosol layer with aerosol concentration $\left(N_{\mathrm{a}}\right)>500 \mathrm{~cm}^{-3}$ was within $100 \mathrm{~m}$ of cloud tops, and 41 separated profiles, where the aerosol layer with $N_{\mathrm{a}}>500 \mathrm{~cm}^{-3}$ was located more than $100 \mathrm{~m}$ above cloud tops. For contact profiles, the average cloud droplet concentration $\left(N_{\mathrm{c}}\right)$ in the cloud layer was up to $68 \mathrm{~cm}^{-3}$ higher, the effective radius $\left(R_{\mathrm{e}}\right)$ up to $1.3 \mu \mathrm{m}$ lower, and the liquid water content (LWC) within $0.01 \mathrm{~g} \mathrm{~m}^{-3}$ compared to separated profiles. Free-tropospheric humidity was higher in the presence of biomass burning aerosols, and contact profiles had a smaller decrease in humidity (and positive buoyancy) across cloud tops with higher median above-cloud $N_{\mathrm{a}}\left(895 \mathrm{~cm}^{-3}\right)$ compared to separated profiles $\left(30 \mathrm{~cm}^{-3}\right)$. Due to droplet evaporation from entrainment
\end{abstract}

mixing of warm, dry free-tropospheric air into the clouds, the median $N_{\mathrm{c}}$ and LWC for contact profiles decreased with height by 21 and $9 \%$ in the top $20 \%$ of the cloud layer. The impact of droplet evaporation was stronger during separated profiles as a greater decrease in humidity (and negative buoyancy) across cloud tops led to greater decreases in median $N_{\mathrm{c}}$ $(30 \%)$ and LWC (16\%) near cloud tops.

Below-cloud $N_{\mathrm{a}}$ was sampled during 61 profiles, and most contact profiles (20 out of 28) were within high- $N_{\mathrm{a}}$ $\left(>350 \mathrm{~cm}^{-3}\right)$ boundary layers, while most separated profiles ( 22 out of 33) were within low- $N_{\mathrm{a}}\left(<350 \mathrm{~cm}^{-3}\right)$ boundary layers. Although the differences in below-cloud $N_{\mathrm{a}}$ were statistically insignificant, contact profiles within low$N_{\mathrm{a}}$ boundary layers had up to $34.9 \mathrm{~cm}^{-3}$ higher $N_{\mathrm{c}}$ compared to separated profiles. This is consistent with a weaker impact of droplet evaporation in the presence of biomass burning aerosols within $100 \mathrm{~m}$ above cloud tops. For contact profiles within high- $N_{\mathrm{a}}$ boundary layers, the presence of biomass burning aerosols led to higher below-cloud $N_{\mathrm{a}}$ (up to $70.5 \mathrm{~cm}^{-3}$ ) and additional droplet nucleation above the cloud base along with weaker droplet evaporation. Con- 
sequently, the contact profiles in high- $N_{\mathrm{a}}$ boundary layers had up to $88.4 \mathrm{~cm}^{-3}$ higher $N_{\mathrm{c}}$ compared to separated profiles. These results motivate investigations of aerosol-cloudprecipitation interactions over the Southeast Atlantic since the changes in $N_{\mathrm{c}}$ and $R_{\mathrm{e}}$ induced by the presence of abovecloud biomass burning aerosols are likely to impact precipitation rates, liquid water path, and cloud fraction, and modulate closed-to-open-cell transitions.

\section{Introduction}

Clouds cover about two-thirds of the Earth's surface (Stubenrauch et al., 2013) and exert a global net cloud radiative effect (CRE) of about $-17.1 \mathrm{~W} \mathrm{~m}^{-2}$ on Earth's energy budget (Loeb et al., 2009). In comparison, the estimated radiative forcing from 1750 to 2011 due to well-mixed greenhouse gases is $+2.83 \mathrm{~W} \mathrm{~m}^{-2}$ (Myhre et al., 2013). The net CRE includes reflection of shortwave solar radiation to space, which cools the Earth, and the absorption (emission) of longwave radiation, which warms (cools) the Earth. Marine stratocumulus is a common cloud type that is observed over oceans off western continental coasts where sea-surface temperatures are low and the boundary layer is capped by a strong inversion (Klein and Hartmann, 1993). From $35^{\circ} \mathrm{S}$ to $35^{\circ} \mathrm{N}$, stratocumulus clouds have a shortwave-plus-longwave topof-the-atmosphere CRE between -150 and $-200 \mathrm{Wm}^{-2}$ with a 10 to $20 \%$ contribution to the net CRE (Oreopoulos and Rossow, 2011). General circulation models have large uncertainties and inter-model spread in estimates of the net CRE (Boucher et al., 2013). This is partly due to strong underestimation of the subtropical marine stratocumulus cloud cover and the associated CRE (Wang and $\mathrm{Su}, 2013$ ).

The radiative impact of stratocumulus depends on many factors, including the horizontal and vertical distribution of cloud droplets, their size distribution, and their number concentration. Stratocumulus properties depend on the number, size, composition, and vertical distribution of aerosols, and meteorological parameters such as boundary layer height, air mass history, and cloud-top instability, all of which can modulate the aerosol loading and influence aerosol-cloud interactions. Increases in aerosols acting as cloud condensation nuclei can increase cloud droplet concentration $\left(N_{\mathrm{c}}\right)$ and decrease effective radius $\left(R_{\mathrm{e}}\right)$, which increases the cloud optical thickness and shortwave reflectance under conditions of constant liquid water content (LWC) (Twomey, 1974, 1977). Cloud adjustments in response to this aerosol indirect effect can modulate LWC. For example, precipitation suppression in clouds with smaller droplets increases LWC and cloud lifetime, which increases the CRE (Albrecht, 1989). The indirect effect and rapid adjustments in clouds contribute to the effective radiative forcing due to aerosol-cloud interactions (Boucher et al., 2013). Estimates of the effective radiative forcing $\left(-1.2\right.$ to $\left.0.0 \mathrm{~W} \mathrm{~m}^{-2}\right)$ have uncertainties that contribute to the total aerosol radiative forcing, which is "the dominant contributor to overall net Industrial Era forcing uncertainty" (Myhre et al., 2013).

The impact of the indirect effect can depend on abovecloud thermodynamic parameters such as humidity, buoyancy, and inversion strength. Depending on the freetropospheric humidity, dry-air entrainment can decrease the LWC in clouds with higher $N_{\mathrm{c}}$ due to the indirect effect (Ackerman et al., 2004; Coakley and Walsh, 2002). Enhanced dry-air entrainment can weaken the increase in cloud optical thickness associated with smaller droplets (Small et al., 2009; Rosenfeld et al., 2014). A weak inversion can lead to increased cloud-top entrainment and initiate a stratocumulus-to-cumulus transition by deepening and decoupling the boundary layer, and cutting off the surface moisture source (Wood, 2012). Evaporative cooling from mixing cloudy air with the warm and dry free-tropospheric air entraining into clouds leads to cloud-top instability, which is the dominant source of turbulence in stratocumulus (Mellado, 2017).

One of the largest stratocumulus cloud decks on Earth exists off the coast of Namibia over the Southeast Atlantic Ocean with a cloud fraction of over $60 \%$ between July and October (Devasthale and Thomas, 2011; Zuidema et al., 2016). Biomass burning aerosols (BBAs) that originate from fires in southern Africa (van der Werf et al., 2010) are transported over the stratocumulus by the southern branch of the African easterly jet and overlay the clouds (Adebiyi and Zuidema, 2016). The aerosol layer over time descends and mixes with clouds, affecting cloud microphysical properties and their satellite retrievals (Haywood et al., 2004; Costantino and Breon, 2010). Rajapakshe et al. (2017) found the aerosol layer was located within $360 \mathrm{~m}$ above the cloud layer for about $60 \%$ of the Cloud-Aerosol Transport System (CATS) lidar nighttime scenes over the Southeast Atlantic. Observations from the NASA ObseRvations of Aerosols above CLouds and their intEractionS (ORACLES) field campaign found the vertical gap between the aerosol layer and cloud tops changed with longitude, having a maximum separation near $7^{\circ} \mathrm{E}$, and had a wide range of values ( 0 to $2000 \mathrm{~m}$ ) with near-zero gap for $48 \%$ of the scenes (LeBlanc et al., 2020). The Southeast Atlantic thus serves as a natural laboratory to examine the effects of varying vertical profiles of above-cloud aerosols on cloud microphysics due to instances of both separation and contact between the BBA layer and the stratocumulus.

BBAs over the Southeast Atlantic have $500 \mathrm{~nm}$ singlescattering albedo ranging between 0.83 and 0.89 (Pistone et al., 2019), which indicates a significant absorbing component to the BBA layer. The warming associated with shortwave absorption by BBAs over the Southeast Atlantic can be amplified by the evaporation of cloud droplets, the semidirect effect (Hansen et al., 1997; Ackerman et al., 2000). Aerosols above a reflective cloud layer absorb more solar radiation than aerosols below or within cloud, which affects 
cloud formation (Haywood and Shine, 1997) and the region's aerosol direct radiative effect (Keil and Haywood, 2003; Cochrane et al., 2019). Shortwave absorption by above-cloud aerosols can increase the buoyancy above cloud tops, inhibit cloud-top entrainment, and increase liquid water path (Wilcox, 2010). Large-eddy simulations indicate that the location of the aerosol layer impacts both the magnitude and sign of the semi-direct forcing (Johnson et al., 2004; McFarquhar and Wang, 2006). For example, aerosols above the boundary layer lead to a stronger inversion and decrease entrainment. Additionally, aerosols within the boundary layer cause cloud evaporation and boundary layer decoupling.

The treatment of aerosol effects results in inter-model differences in climate simulations, along with biases in satellite retrievals of clouds and aerosols (Haywood et al., 2004; Brioude et al., 2009; Chand et al., 2009; Coddington et al., 2010; Painemal and Zuidema, 2011). Many large-scale models do not adequately consider cloud microphysical responses to the vertical separation of aerosols when evaluating aerosol-cloud interactions (Hill et al., 2008). The ORACLES field campaign provides a unique dataset of in situ observations of cloud and aerosol properties over the Southeast Atlantic (Redemann et al., 2021). The impact of above-cloud BBAs on stratocumulus properties is quantified by comparing in situ cloud measurements from instances with layer separation to instances of contact between the aerosol layer and the clouds.

The remainder of the paper is organized as follows. The instrumentation used in the analysis is described in Sect. 2 along with the procedures for processing the data. A case study of the 6 September 2016 research flight is presented in Sect. 3. The meteorological and aerosol conditions present are examined, and profiles of $N_{\mathrm{c}}, R_{\mathrm{e}}$, and LWC are compared for four sawtooth maneuvers flown at locations where clouds were in contact with and separated from above-cloud BBAs. In Sect. 4, measurements from six research flights are analyzed to investigate buoyancy associated with cloudtop evaporative cooling, and profiles of $N_{\mathrm{c}}, R_{\mathrm{e}}$, and LWC are compared for boundary layers with similar and varying aerosol loading. Finally, the conclusions and their impact on the understanding of aerosol-cloud interactions are discussed in Sect. 5.

\section{Instrumentation}

This study presents in situ measurements of cloud and aerosol properties acquired during the first intensive observation period (IOP) of ORACLES based at Walvis Bay, Namibia $\left(23^{\circ} \mathrm{S}, 14.6^{\circ} \mathrm{E}\right)$. The NASA P-3B aircraft conducted research flights west of Africa over the Southeast Atlantic Ocean between $1^{\circ} \mathrm{W}$ to $15^{\circ} \mathrm{E}$ and $5^{\circ} \mathrm{S}$ to $25^{\circ} \mathrm{S}$ from 27 August to 27 September 2016. The aircraft typically flew $50 \mathrm{~m}$ to $7 \mathrm{~km}$ above the ocean surface and was equipped with in situ probes for sampling aerosols, clouds, and meteoro- logical conditions (Table 1), among other instrumentation. The Passive Cavity Aerosol Spectrometer Probe (PCASP) measured aerosol from approximately 0.1 to $3.0 \mu \mathrm{m}$ using three voltage amplifiers: high-, middle-, and low-gain stages (Cai et al., 2013). Laboratory sampling of ammonium sulfate particles conducted after the IOP with the PCASP and a scanning mobility particle size spectrometer (SMPS) adjusted the PCASP concentration within each amplification stage to match the measured SMPS concentration. Thereby, a low bias within the middle- and high-gain stages was corrected to calculate the total aerosol concentration $\left(N_{\mathrm{a}}\right)$.

A high-resolution time-of-flight aerosol mass spectrometer (HR-ToF-AMS, or AMS) is used to derive the aerosol mass $\left(M_{\mathrm{a}}\right)$ and chemistry, including organic aerosols (OAs) (Table 1). A time- and composition-dependent collection efficiency (CE) was applied to AMS data. The molar ratio of ammonium to sulfate $\left(\mathrm{NH}_{4} /\left(2 \times \mathrm{SO}_{4}\right)\right)$ was calculated to assess the acidity of liquid aerosol, which is collected more efficiently compared to neutralized aerosol. Thus, $\mathrm{CE}$ was determined as the maximum between 0.5 and $\left(1-\mathrm{NH}_{4} /\left(2 \times \mathrm{SO}_{4}\right)\right)$, with a value of 0.5 serving as the lower limit, consistent with estimates from most previous field campaigns (Middlebrook et al., 2012). A Single Particle Soot Photometer (SP2) measured refractory black carbon (rBC) concentration, and a $\mathrm{CO} / \mathrm{CO}_{2} / \mathrm{H}_{2} \mathrm{O}$ gas analyzer measured carbon monoxide (CO) concentration. The Spectrometer for Sky-Scanning, Sun-Tracking Atmospheric Research (4STAR) was used to measure column aerosol optical depth (AOD) and retrieve trace gas concentrations above the aircraft (Dunagan et al., 2013; LeBlanc et al., 2020).

The suite of in situ cloud probes included the Cloud and Aerosol Spectrometer (CAS) on the Cloud, Aerosol, and Precipitation Spectrometer (CAPS); Cloud Droplet Probe (CDP); Phase Doppler Interferometer; Two-Dimensional Stereo Probe (2D-S); Cloud Imaging Probe (CIP) on the CAPS; High Volume Precipitation Sampler (HVPS-3); and the CAPS and King hot wires. These instruments sampled the droplet number distribution function $(n(\mathrm{D}))$ for droplets with diameters ranging from 0.5 to $19200 \mu \mathrm{m}$. The CAPS and King hot wires measured the bulk LWC. Baumgardner et al. (2017) discuss the general operating characteristics and measurement uncertainties of the in situ cloud probes, and McFarquhar et al. (2017) summarize data processing algorithms. Therefore, only aspects of instrument performance unique to ORACLES 2016 are summarized herein. The in situ probes used here (CAS, 2D-S, HVPS-3, and PCASP) were calibrated by the manufacturers prior to and shortly after the deployment. During the deployment, performance checks according to the instrument manuals were completed to determine any change in instrument performance. This included monitoring the CAS and 2D-S voltages and temperatures during flights and passing calibration particles through the CAS sample volume to determine any change in the relationship between particle size and peak signal voltage. 
Table 1. The main parameter used, sampling frequency, and measurement range for in situ instruments installed on the P-3 research aircraft and used within this study.

\begin{tabular}{lllll}
\hline Instrument & Parameter used & $\begin{array}{l}\text { Sampling } \\
\text { frequency }\end{array}$ & Measurement range & Reference \\
\hline Rosemount 102 & Temperature & $1 \mathrm{~Hz}$ & Nominally -50 to $50^{\circ} \mathrm{C}$ & Rosemount, Incorporated \\
\hline Rosemount MADT 2014 & Pressure & $1 \mathrm{~Hz}$ & Nominally $30-1300 \mathrm{mb}$ & Rosemount, Incorporated \\
\hline $\begin{array}{l}\text { EdgeTech 137 chilled-mirror } \\
\text { hygrometer }\end{array}$ & Dew point temperature & $1 \mathrm{~Hz}$ & Nominally -40 to $60^{\circ} \mathrm{C}$ & EdgeTech Instruments \\
\hline Global Positioning System & $\begin{array}{l}\text { Latitude, longitude, } \\
\text { altitude }\end{array}$ & $1 \mathrm{~Hz}$ & -90 to $90^{\circ}$ & \\
\hline CO/CO 2 Analyzer & CO, $\mathrm{H}_{2} \mathrm{O}(\mathrm{v})$ & $1 \mathrm{~Hz}$ & 5 to $50000 \mathrm{ppb}$, & \\
\hline CAS & Droplet $n$ (D) & $10 \mathrm{~Hz}$ & $0.5-50 \mu \mathrm{m}$ & Los Gatos Research \\
\hline 2D-S & $\begin{array}{l}\text { Droplet images, } \\
\text { asynchronous } n(\mathrm{D})\end{array}$ & & Nominally 10-1280 $\mu \mathrm{m}$ & Lawson et al. (2006) \\
\hline HVPS-3 & $\begin{array}{l}\text { Droplet images, } \\
\text { asynchronous } n(\mathrm{D})\end{array}$ & & Nominally $150-19200 \mu \mathrm{mm}$ & Lawson et al. (1998) \\
\hline King hot wire & Bulk LWC & $25 \mathrm{~Hz}$ & $0.05-3 \mathrm{~g} \mathrm{~m}{ }^{-3}$ & King et al. (1978) \\
\hline PCASP & Aerosol $n$ (D) & $10 \mathrm{~Hz}$ & $0.1-3 \mu \mathrm{m}$ & Strapp et al. (1992) \\
\hline SP2 & Aerosol absorption & $1 \mathrm{~Hz}$ & $55-524 \mathrm{~nm}$ & Stephens et al. (2003) \\
\hline HR-ToF-AMS & Aerosol mass & $0.2 \mathrm{~Hz}$ & $50-700 \mathrm{~nm}$ & Drewnick et al. (2005) \\
\hline & & &
\end{tabular}

CDP data were unusable for the entire 2016 IOP due to an optical misalignment issue. Data from the components of CAPS (CAS, CIP, and CAPS hot wire) were not available before 6 September 2016 because of improper seating of the analog-to-digital interface board, which resulted in no measurements of droplets less than $50 \mu \mathrm{m}$ in diameter prior to this flight. The optical lenses were cleaned with isopropyl before each flight, which was especially important during ORACLES since the aircraft frequently flew through aerosol layers that deposited soot on optical lenses of the cloud probes. Stuck bits (photodiodes continuously occluded due to soot deposition) on the optical array probes (2D-S and HVPS-3) were masked during each flight to reduce the presence of artifacts in particle images. The 2D-S vertical channel consistently had photodiode voltages below $1.0 \mathrm{~V}$ due to soot deposition on the inside of the receive-side mirror. Therefore, only data from the horizontal channel are used.

The aircraft's true air speed (TAS) was about $15 \%$ higher than the TAS measured by a Pitot tube alongside the CIP. Previous work has shown uncertainties with using the Pitot tube TAS to represent airflow near the probes (Lance et al., 2010; Johnson et al., 2012). Therefore, CAPS, 2D-S, and HVPS- 3 probes used the aircraft's TAS, in the absence of reliable TAS measured at these probes' locations. CAPS and PCASP data were processed using the Airborne Data Processing and Analysis processing package (Delene, 2011).
2D-S and HVPS-3 data were processed using the University of Illinois/Oklahoma Optical Array Probe Processing Software (McFarquhar et al., 2018). Droplets measured by the 2D-S and HVPS-3 having aspect ratios greater than 4 or area ratios less than 0.5 were rejected as artifacts because this study focuses on warm clouds with liquid drops sampled above $0{ }^{\circ} \mathrm{C}$. Droplets with inter-arrival times less than $6 \mu \mathrm{s}$, indicative of intermittently stuck diodes or drizzle breakup, were removed (Field et al., 2006). Out-of-focus hollow particles were reconstructed following Korolev (2007).

The droplet size distributions from the CAS and 2D$S$ were merged at $50 \mu \mathrm{m}$ in diameter to create a combined $1 \mathrm{~Hz}$ size distribution, which was used to calculate $N_{\mathrm{c}}, R_{\mathrm{e}}$, and LWC. While the HVPS-3 sampled droplets larger than $1280 \mu \mathrm{m}$ in diameter, only three such $1 \mathrm{~s}$ samples, with $N<0.005 \mathrm{~L}^{-1}$, were sampled during the cloud profiles from the IOP. A threshold of $N_{\mathrm{c}}>10 \mathrm{~cm}^{-3}$ and bulk LWC $>0.05 \mathrm{~g} \mathrm{~m}^{-3}$ for $1 \mathrm{~Hz}$ measurements was used to define cloud samples (cf. Lance et al., 2010; Bretherton et al., 2010). The cloud threshold eliminated the inclusion of optically thinner clouds that a lower LWC threshold of $0.01 \mathrm{~g} \mathrm{~m}^{-3}$ would have included (e.g., Heymsfield and McFarquhar, 2001). Water vapor mixing ratio $(q)$ was determined using a chilled-mirror hygrometer as well as the Los Gatos Research $\mathrm{CO} / \mathrm{CO}_{2} / \mathrm{H}_{2} \mathrm{O}$ gas analyzer. The hygrometer suffered from cold soaking during descents from higher ele- 


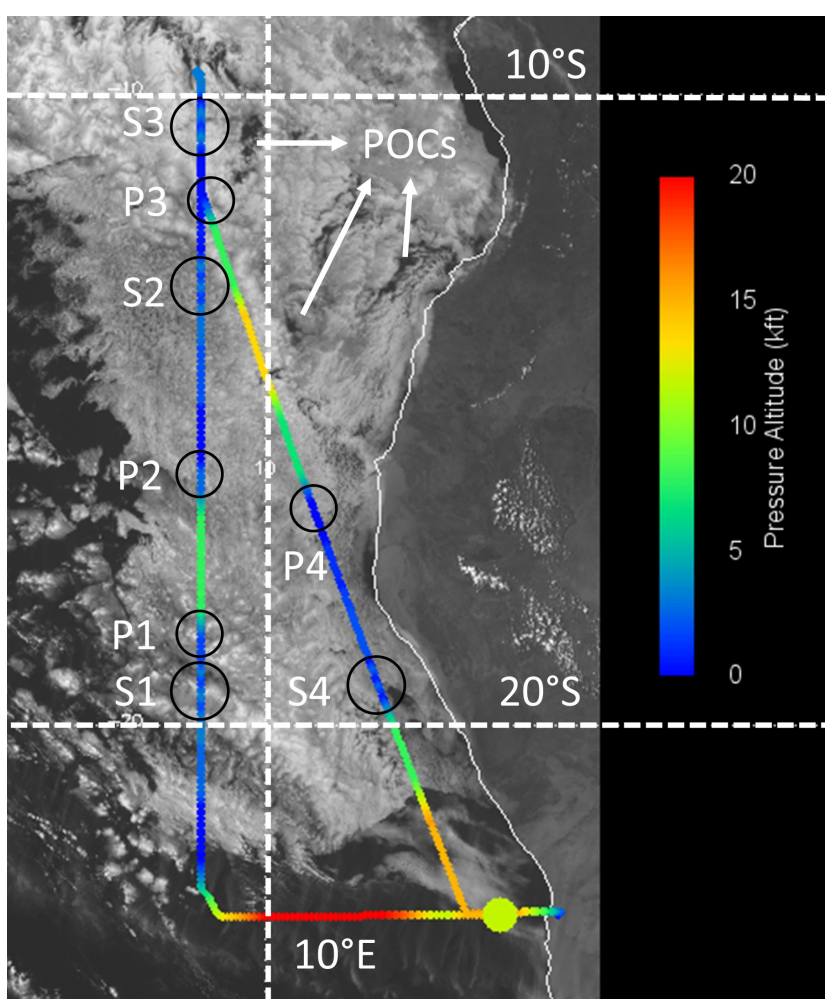

Figure 1. Visible image from the Spinning Enhanced Visible and Infrared Imager at 14:00 UTC on 6 September 2016 (PRF5), overlaid by the PRF5 flight track and colored by flight altitude. Circles indicate sawtooth maneuver $(\mathrm{S})$ and individual cloud profile $(\mathrm{P})$ locations (https://bocachica.arc.nasa.gov/ORACLES/, last access: 22 March 2021).

vation and measured lower $q$ near cloud tops during descents compared to ascents into cloud. Measurements of $q$ from the gas analyzer had to be masked for near- and in-cloud samples during both ascents and descents due to residual water in the inlet. Therefore, only hygrometer data collected during ascents are used for the analyses involving $q$.

\section{Observations on 6 September 2016}

\subsection{Flight track and meteorological conditions}

ORACLES research flight tracks included in situ cloud sampling during individual ascents or descents through cloud or during a series of ascents and descents through cloud along a constant heading (sawtooth maneuvers). A case study of the fifth P-3 research flight (PRF5) flown on 6 September 2016 was used to examine aerosol and cloud properties sampled under conditions of both contact and separation between the aerosol layer and cloud tops. PRF5 was selected because it had the highest cloud profiling time among the six PRFs with at least eight cloud profiles (Table 2). Four sawtooth maneuvers (S1-S4) were flown during PRF5 (Fig. 1) along with four individual cloud profiles (P1-P4). Each sawtooth maneuver consisted of four to six individual profiles (Table 2), which were numbered sequentially (S1-1, S1-2, etc.). Southsoutheasterly winds $\left(5-8 \mathrm{~m} \mathrm{~s}^{-1}\right)$ were observed at the surface and at $925 \mathrm{mb}$ (Fig. 2a and b). This wind field was associated with a surface low-pressure system east of the study region centered around $17^{\circ} \mathrm{S}, 13^{\circ} \mathrm{E}$, which resulted in advection of low clouds toward the northwest. Open and closed cells of marine stratocumulus persisted along with pockets of open cells (POCs) (Fig. 1). S1, S2, and S3 were flown along $9^{\circ} \mathrm{E}$ in closed cells of marine stratocumulus. S4 was flown closer to the coast in a shallow boundary layer with thin closed-cell stratocumulus (Fig. 1) later in the day compared to S1-S3 (Fig. 3). Ambient temperature sampled by the aircraft sensor was 3 to $6{ }^{\circ} \mathrm{C}$ higher during S2 and S3 compared to $\mathrm{S} 1$ because the $500 \mathrm{mb}$ geopotential height and relative humidity ( $\mathrm{RH})$ were higher toward the north (Fig. 2b). Cloud-top height $\left(Z_{\mathrm{T}}\right)$ is identified as the highest altitude satisfying the criteria used to define cloud $\left(N_{\mathrm{c}}>10 \mathrm{~cm}^{-3}\right.$ and bulk $\mathrm{LWC}>0.05 \mathrm{~g} \mathrm{~m}^{-3}$ ). S1, S2, and $\mathrm{S} 3$ had higher $Z_{\mathrm{T}}$ compared to S4 (Fig. 3) due to the advection of cold, dry continental air from the southeast and low RH $(<70 \%)$ where S4 was flown, which resulted in cloud thinning and a shallower boundary layer (Fig. 2b and c).

The aircraft intermittently entered and exited cumulus clouds below the stratocumulus layer during 33 of the 71 cloud profiles flown during the IOP (Table 2), which resulted in fluctuating values of $N_{\mathrm{c}}$ and $R_{\mathrm{e}}$, with bulk LWC $<0.05 \mathrm{~g} \mathrm{~m}^{-3}$. For example, during S1-3, $N_{\mathrm{c}}$ varied between 10 and $240 \mathrm{~cm}^{-3}$, and $R_{\mathrm{e}}$ varied between 3 and $12 \mu \mathrm{m}$ up to $130 \mathrm{~m}$ below where the stratocumulus base was identified with bulk $\mathrm{LWC}>0.05 \mathrm{~g} \mathrm{~m}^{-3}$. Images from a forward-facing camera on the aircraft contrast a boundary layer with multiple cloud layers (Fig. 4a; image taken at 08:53 UTC) during S1-3 and a shallow, well-mixed boundary layer capped by stratocumulus (Fig. $4 \mathrm{~b}$; image taken at 13:16 UTC) during S4-1. It is likely the stratocumulus layer was decoupled from the surface where S1-3 was flown because the boundary layer was deepened by the entrainment of free-tropospheric air. Subsequently, the sub-cloud layer was well-mixed with the surface and topped by shallow cumulus similar to observations by Wood (2012). The cloud base height $\left(Z_{\mathrm{B}}\right)$ for the 33 profiles was determined as the lowest altitude with $N_{\mathrm{c}}>10 \mathrm{~cm}^{-3}$ and bulk LWC $>0.05 \mathrm{~g} \mathrm{~m}^{-3}$ above which a continuous cloud layer was sampled. S4 had lower $Z_{\mathrm{B}}(195-249 \mathrm{~m})$ compared to $\mathrm{S} 1(676-691 \mathrm{~m}), \mathrm{S} 2$ (534-598 m), and S3 (501-775 m) (Fig. 3).

\subsection{Above- and below-cloud aerosol composition}

For each sawtooth maneuver, the above- and below-cloud air mass source region was identified using $5 \mathrm{~d}$ back trajectories computed using the NOAA Hybrid Single-Particle Lagrangian Integrated Trajectory model (Stein et al., 2015) applied to the National Centers for Environmental Predic- 
Table 2. List of research flights analyzed with the number of cloud profiles flown and total time spent profiling clouds during each flight. The number of profiles during sawtooth maneuvers are reported within parentheses. The number of profiles and the corresponding sampling time are reported for contact and separated profiles during each flight.

\begin{tabular}{lllll}
\hline Flight & $\begin{array}{l}\text { Sawtooth }+ \\
\text { individual profiles }\end{array}$ & Cloud time & $\begin{array}{l}\text { Contact } \\
\text { profiles }\end{array}$ & $\begin{array}{l}\text { Separated } \\
\text { profiles }\end{array}$ \\
\hline PRF5: 6 Sep & $4(4,5,4,6)+5$ & $1327 \mathrm{~s}$ & $13(857 \mathrm{~s})$ & $11(470 \mathrm{~s})$ \\
PRF7: 10 Sep & $1(2)+7$ & $461 \mathrm{~s}$ & $0(0 \mathrm{~s})$ & $9(461 \mathrm{~s})$ \\
PRF8: 12 Sep & $1(6)+2$ & $504 \mathrm{~s}$ & $1(32 \mathrm{~s})$ & $7(472 \mathrm{~s})$ \\
PRF9: 14 Sep & $0(0)+8$ & $574 \mathrm{~s}$ & $0(0 \mathrm{~s})$ & $8(574 \mathrm{~s})$ \\
PRF11: 20 Sep & $1(7)+6$ & $669 \mathrm{~s}$ & $13(669 \mathrm{~s})$ & $0(0 \mathrm{~s})$ \\
PRF13: 25 Sep & $2(2,3)+4$ & $511 \mathrm{~s}$ & $3(148 \mathrm{~s})$ & $6(363 \mathrm{~s})$ \\
\hline Total & $9(39)+32$ & $1 \mathrm{~h} \mathrm{7min} \mathrm{26s}$ & $30(1706 \mathrm{~s})$ & $41(2340 \mathrm{~s})$ \\
\hline
\end{tabular}
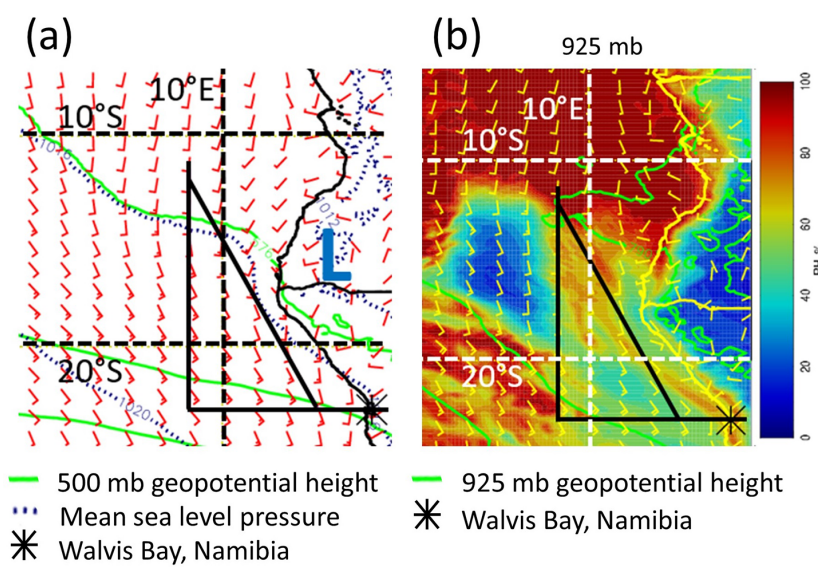

(c)

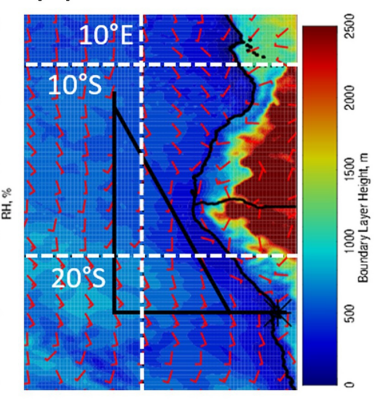

* Walvis Bay, Namibia

*.. Mean sea level pressur

* Walvis Bay, Namibia

Figure 2. Zero-hour European Centre for Medium-Range Weather Forecasts reanalysis at 12:00 UTC on 6 September 2016 for (a) mean sea level pressure, $500 \mathrm{mb}$ geopotential height, and surface wind; (b) $925 \mathrm{mb}$ relative humidity, geopotential height, and wind; and (c) boundary layer height and $900 \mathrm{mb}$ wind (https://bocachica.arc.nasa.gov/ORACLES/, last access: 22 March 2021).

tion Global Data Assimilation System model (Fig. 5). The concentrations listed in Table 3 indicate measurements up to $100 \mathrm{~m}$ above and below the clouds averaged across the cloud profiles for each sawtooth maneuver. The variability in above-cloud $M_{\mathrm{a}}$ and $N_{\mathrm{a}}$ for $\mathrm{S} 1-\mathrm{S} 4$ was driven by the abovecloud air mass source region. The above-cloud air mass sampled near S1 and S4 originated from the boundary layer from the southeast, and the above-cloud air mass sampled near S2 and $\mathrm{S} 3$ descended from higher altitudes over the African continent (Fig. $5 \mathrm{~b}$ and c). The above-cloud OA $M_{\mathrm{a}}$ and $N_{\mathrm{a}}$ for S2 and $\mathrm{S} 3$ were over 5 times higher than the corresponding values for S1 and S4 (Table 3). The below-cloud air mass sampled during S1-S4 was advected from the boundary layer from the southeast (Fig. 5a and c). During S1 and S4, the above- and below-cloud $\mathrm{rBC}$ and $\mathrm{CO}$ concentrations were similar (Table 3) since the above-cloud air mass also originated from the southeast (Fig. 5b and c). During S2 and S3, the continental above-cloud air mass had much higher $\mathrm{rBC}$ and $\mathrm{CO}$ (over $500 \mathrm{~cm}^{-3}$ and $190 \mathrm{ppb}$ ) compared to the below-cloud air mass from the southeast (below $150 \mathrm{~cm}^{-3}$ and $120 \mathrm{ppb}$ ). Since OA, rBC, and CO are indicators of com- bustion, this suggests the continental above-cloud air mass had greater exposure to biomass burning products compared to the air masses from the southeast. S2 and S3 also had higher below-cloud $\mathrm{rBC}$ and $\mathrm{CO}$ compared to $\mathrm{S} 1$ and $\mathrm{S} 4$ (Table 3), which suggests the BBAs with high $N_{\mathrm{a}}$ within $100 \mathrm{~m}$ above clouds could be mixing into the cloud layer and polluting the boundary layer. This is also likely to be associated with the history of entrainment mixing of polluted freetropospheric air into the boundary layer prior to these observations (Diamond et al., 2018).

\subsection{Cloud profile classification}

Every sawtooth maneuver was preceded by a 5-10 min constant-altitude flight leg about $100 \mathrm{~m}$ above the cloud layer to retrieve the above-cloud AOD using 4STAR. Average above-cloud AOD at $550 \mathrm{~nm}$ within $50 \mathrm{~km}$ of the sampling locations for $\mathrm{S} 1-\mathrm{S} 4$ ranged between 0.33 and 0.49 , indicating a BBA layer was located at some altitude above the clouds sampled during S1-S4. During S1, abovecloud $N_{\mathrm{a}}<500 \mathrm{~cm}^{-3}$ was sampled up to $200 \mathrm{~m}$ above cloud 
S1

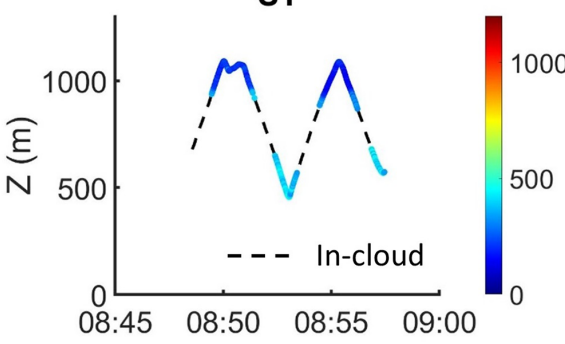

S3

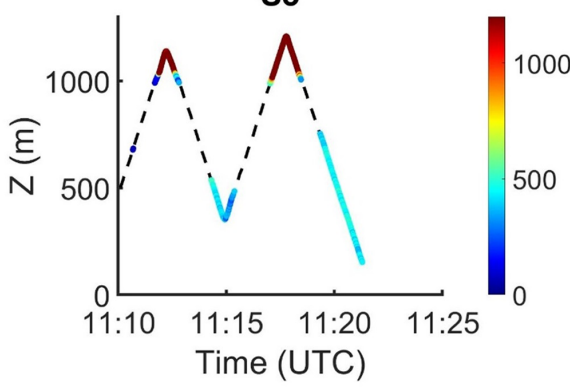

S2

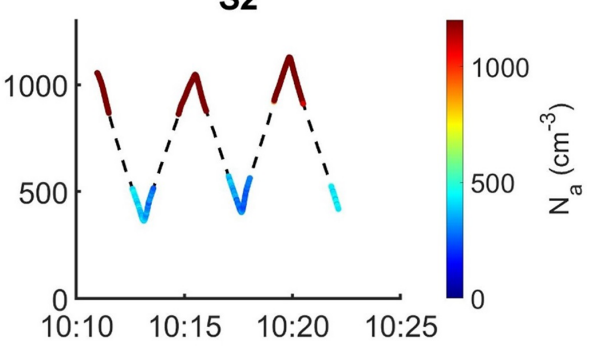

S4

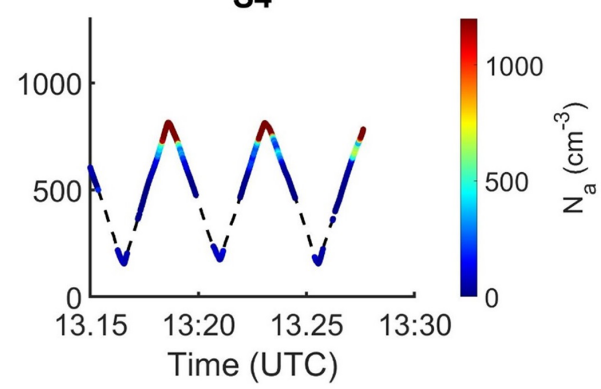

Figure 3. P-3 aircraft altitude as a function of time, colored by PCASP accumulation mode $(0.1<D<3 \mu \mathrm{m}) N_{\mathrm{a}}$ for four sawtooth maneuvers flown on 6 September 2016. In-cloud $N_{\mathrm{a}}$ are masked due to potential for droplet shattering on the PCASP probe inlet.

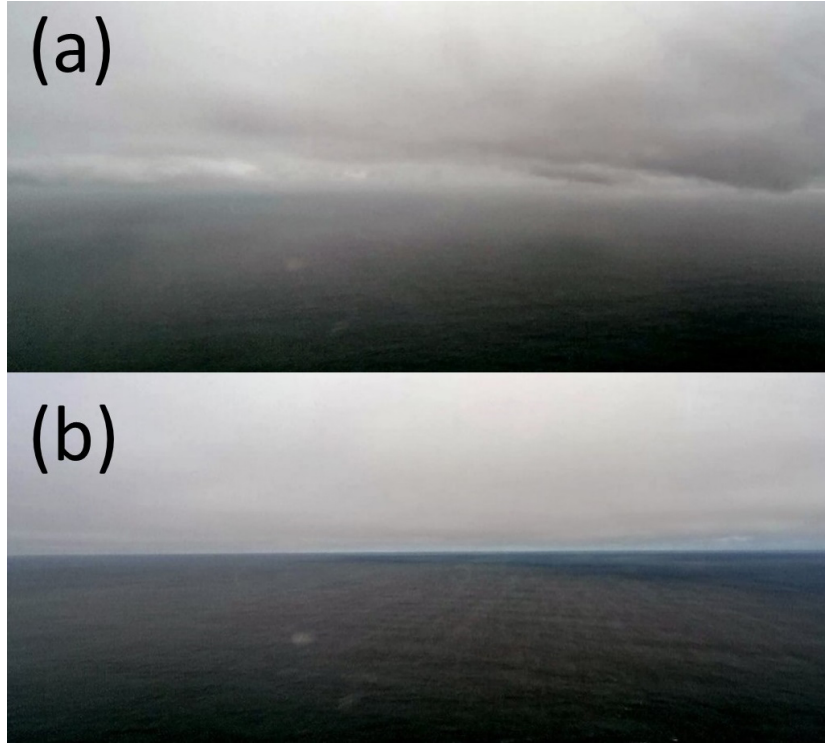

Figure 4. Snapshots of the boundary layer sampled below (a) S1 showing shallow cumulus and stratocumulus layers with varying bases, and (b) S4 showing stratocumulus clouds with a uniform base (NSRC/NASA Airborne Science Program).

tops (Fig. 3), which indicates the BBA layer was separated from cloud tops. During S4, the level of above-cloud $N_{\mathrm{a}}>500 \mathrm{~cm}^{-3}$ was identified over $200 \mathrm{~m}$ above cloud tops, indicating a similar separation. Therefore, cloud profiles flown during $\mathrm{S} 1$ and $\mathrm{S} 4$ were classified as separated profiles. During S2 and S3, the level of above-cloud $N_{\mathrm{a}}>500 \mathrm{~cm}^{-3}$
Table 3. The total $\left(\mathrm{OA}+\mathrm{SO}_{4}^{2+}+\mathrm{NH}_{4}^{+}+\mathrm{NO}_{3}^{-}\right)$and $\mathrm{OA} M_{\mathrm{a}}$, PCASP $N_{\mathrm{a}}$, and $\mathrm{rBC}$ and $\mathrm{CO}$ concentrations sampled up to $100 \mathrm{~m}$ below cloud base and $100 \mathrm{~m}$ above cloud top during four sawtooth maneuvers (S1-S4) flown on 6 September 2016. These values correspond to averages across the individual profiles flown during S1S4. AOD was sampled during constant altitude flight legs and corresponds to the atmospheric column above the aircraft.

\begin{tabular}{llrrrr}
\hline Parameter & Location & S1 & S2 & S3 & S4 \\
\hline Total $M_{\mathrm{a}}\left(\mu \mathrm{g} \mathrm{m}^{-3}\right)$ & Above cloud & 3.4 & 22.9 & 21.7 & 0.8 \\
& Below cloud & 4.5 & 5.9 & 5.7 & 1.4 \\
OA $M_{\mathrm{a}}\left(\mu \mathrm{g} \mathrm{m}^{-3}\right)$ & Above cloud & 2.0 & 16.9 & 13.2 & 0.4 \\
& Below cloud & 1.9 & 3.5 & 3.4 & 1.0 \\
PCASP $N_{\mathrm{a}}\left(\mathrm{cm}^{-3}\right)$ & Above cloud & 241 & 1515 & 1334 & 16 \\
& Below cloud & 354 & 327 & 390 & 72 \\
$\mathrm{rBC}\left(\mathrm{cm}^{-3}\right)$ & Above cloud & 66 & 516 & 700 & 10 \\
$\mathrm{CO}(\mathrm{ppb})$ & Below cloud & 72 & 111 & 130 & $\mathrm{NA}$ \\
& Above cloud & 95 & 196 & 230 & 96 \\
$\mathrm{AOD}$ & Below cloud & 93 & 103 & 117 & 88 \\
& Above cloud & 0.33 & 0.37 & 0.49 & 0.39 \\
\hline
\end{tabular}

NA: not available.

was located within $100 \mathrm{~m}$ above cloud tops, and the BBA layer was likely in contact with the cloud tops. Therefore, cloud profiles flown during S2 and S3 were classified as contact profiles. In a previous study, a significantly higher threshold (PCASP $N_{\mathrm{a}}=1000 \mathrm{~cm}^{-3}$ ) was used to identify the BBA layer above stratocumulus clouds off the coast of California (Mardi et al., 2018). The sensitivity of the threshold chosen in this study is examined in Appendix A, and using a 

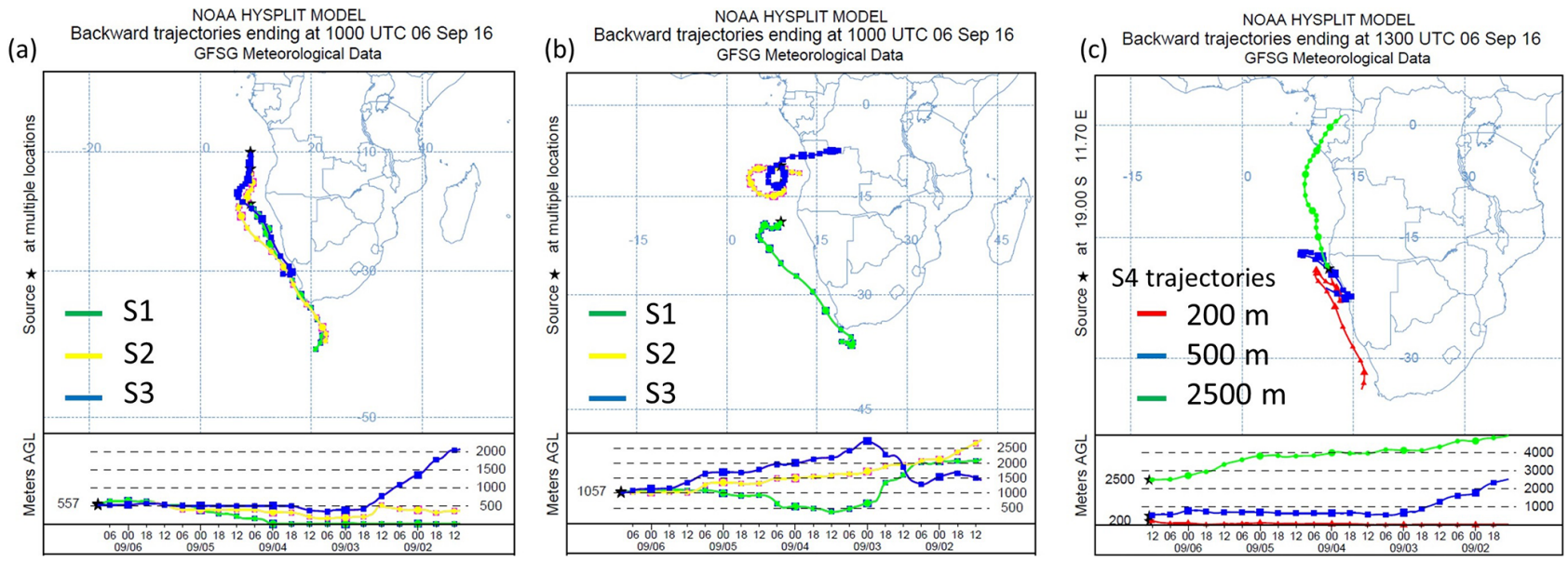

Figure 5. Five-day back trajectories from the Hybrid Single-Particle Lagrangian Integrated Trajectory model for sawtooth maneuvers flown on 6 September 2016 (a) ending at 10:00 UTC for S1-S3 at 500 ma.m.s.l.; (b) ending at 10:00 UTC for S1-S3 at 1000 ma.m.s.1.; and (c) ending at 13:00 UTC for S4 at 200, 500, and $2500 \mathrm{~m}$ a.m.s.l.
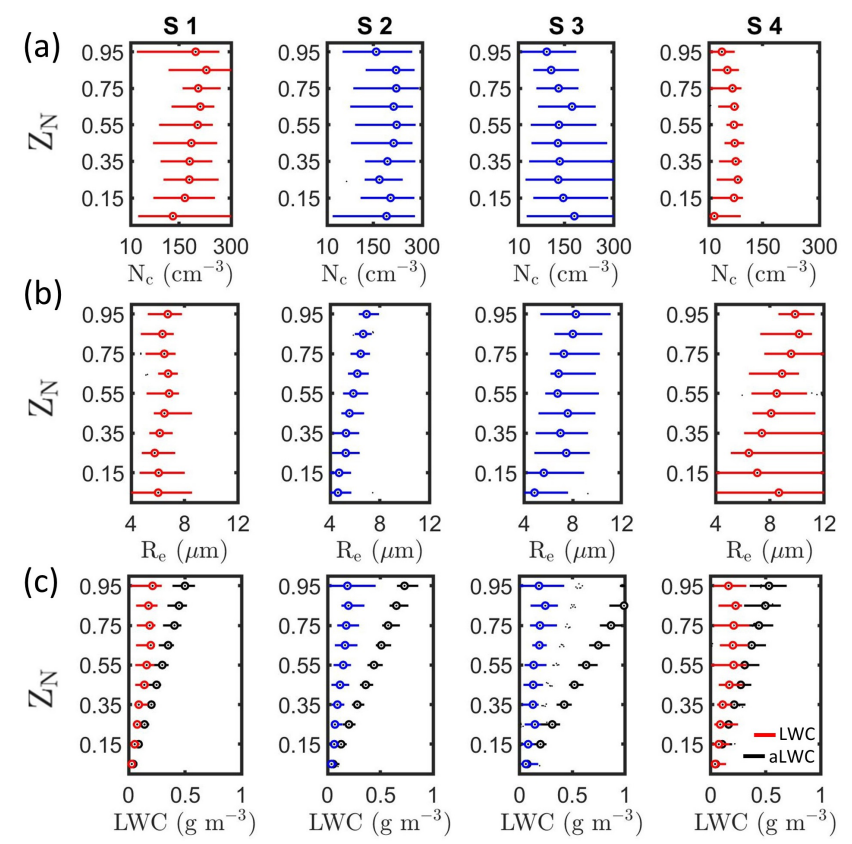

Figure 6. Vertical profiles of (a) $N_{\mathrm{c}}$, (b) $R_{\mathrm{e}}$, and (c) LWC and aLWC as a function of $Z_{\mathrm{N}}$ for the four sawtooth maneuvers. Maneuvers with contact (separation) between the biomass burning aerosol layer and cloud tops shown in blue (red).

threshold of $1000 \mathrm{~cm}^{-3}$ would have no significant impact on the results presented in this study.

\subsection{Vertical profiles of $N_{\mathrm{c}}, R_{\mathrm{e}}$, and LWC}

Since $Z_{\mathrm{B}}$ and cloud thickness $(H)$ varied between profiles, $N_{\mathrm{c}}, R_{\mathrm{e}}$, and LWC were examined as a function of normalized height above cloud base $\left(Z_{\mathrm{N}}\right)$, where $Z_{\mathrm{N}}=(Z-$ $\left.Z_{\mathrm{B}}\right) /\left(Z_{\mathrm{T}}-Z_{\mathrm{B}}\right)$ and varied from 0 (cloud base) to 1 (cloud top). Measurements from the four sawtooth maneuvers were compared following McFarquhar et al. (2007) and divided into $10 Z_{\mathrm{N}}$ bins, where each bin represented $10 \%$ of the cloud layer (Fig. 6). For example, the bin with $0<Z_{N}<0.1$ (represented by the midpoint, $Z_{\mathrm{N}}=0.05$ ) included data collected over the bottom $10 \%$ of the cloud layer. For separated profiles, droplet nucleation occurred near cloud base with the median $N_{\mathrm{c}}$ increasing up to $Z_{\mathrm{N}}=0.25$ (S1: 132 to $179 \mathrm{~cm}^{-3}$; S4: 23 to $85 \mathrm{~cm}^{-3}$ ). The impact of droplet nucleation decreased above cloud base $\left(Z_{\mathrm{N}}=0.25\right.$ to 0.75$)$, and median $N_{\mathrm{c}}$ increased by up to $30 \mathrm{~cm}^{-3}$ for $\mathrm{S} 1$ and decreased by up to $15 \mathrm{~cm}^{-3}$ for S4 (Fig. 6a). Condensational growth occurred over these levels as the median $R_{\mathrm{e}}$ increased with $Z_{\mathrm{N}}$ (Fig. 6b). The median $N_{\mathrm{c}}$ decreased near cloud top $\left(Z_{\mathrm{N}}=0.75\right.$ to 0.95$)$ due to droplet evaporation resulting from cloud-top entrainment mixing between cloudy and noncloudy air. Contact profiles (S2 and S3) had higher median $N_{\mathrm{c}}$ at cloud base compared to separated profiles, which decreased with height up to $Z_{\mathrm{N}}=0.25$ (S2: 190 to $169 \mathrm{~cm}^{-3}$, S3: 180 to $131 \mathrm{~cm}^{-3}$ ). The median $N_{\mathrm{c}}$ for $\mathrm{S} 2$ and $\mathrm{S} 3$ increased by up to $43 \mathrm{~cm}^{-3}$ over $Z_{\mathrm{N}}=0.25$ to 0.75 and decreased near cloud top due to droplet evaporation. $\mathrm{S} 4$ had the lowest $N_{\mathrm{c}}$ at cloud base because the below-cloud $M_{\mathrm{a}}$ and $N_{\mathrm{a}}$ for S4 were over a factor of 3 lower than the corresponding values for S1-S3 (Table 3).

Consistent with condensational growth and collisioncoalescence, median $R_{\mathrm{e}}$ increased with $Z_{\mathrm{N}}$ from cloud base to top, from 6.0 to $6.7 \mu \mathrm{m}, 4.6$ to $6.9 \mu \mathrm{m}, 4.9$ to $8.3 \mu \mathrm{m}$, and 8.7 to $9.9 \mu \mathrm{m}$ for $\mathrm{S} 1-\mathrm{S} 4$, respectively (Fig. $6 \mathrm{~b}$ ). S1 and S4 had higher median $R_{\mathrm{e}}$ at cloud base due to higher drizzle (droplets with diameters larger than $50 \mu \mathrm{m}$ ) concentrations (41 and $31 \mathrm{~L}^{-1}$ ) compared to S2 and S3 $\left(14\right.$ and $18 \mathrm{~L}^{-1}$ ). For $\mathrm{S} 4$, drizzle concentration decreased from $Z_{\mathrm{N}}=0.05$ to 0.25 , which led to the decrease in median $R_{\mathrm{e}}$ over these heights. The median LWC increased with height up to at least 

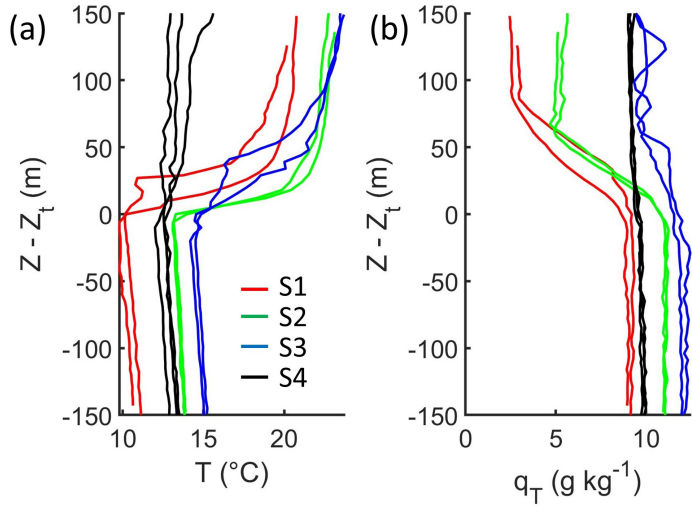

Figure 7. Vertical profiles of (a) $T$ and (b) $q_{T}$ as a function of distance from cloud top. Each line corresponds to an individual ascent through cloud during a sawtooth. The profiles flown during S2 and S3 (S1 and S4) had contact (separation) between the above-cloud biomass burning aerosol layer and cloud tops.

$Z_{\mathrm{N}}=0.75$ and decreased near cloud tops due to droplet evaporation (Fig. 6c). The LWC for each sawtooth maneuver was lower than the adiabatic LWC (aLWC) due to cloud-top entrainment mixing, and the ratio of LWC to aLWC was used to quantify the degree of mixing. Lower LWC/aLWC (averaged over the cloud layer) for S2 and S3 (0.37 and 0.41) compared to S1 and S4 (0.51 and 0.55) indicated that contact profiles had greater mixing between cloudy and noncloudy air in the cloud layer, on average. The boundary layer was capped by an inversion with warmer, drier air above the clouds. During S1-S4, the temperature increased above cloud top by $10.3,9.3,8.9$, and $1.5^{\circ} \mathrm{C}$, and the total water mixing ratio decreased by $6.2,5.4,2.3$, and $0.4 \mathrm{~g} \mathrm{~kg}^{-1}$, respectively (Fig. 7). The decreases in $N_{\mathrm{c}}$ and LWC near stratocumulus tops have been attributed to cloud-top entrainment of the overlying warm and sub-saturated air (Wood, 2012). Droplet evaporation due to the entrainment mixing resulted in decreases of $14,28,12$, and $26 \%$ in the median $N_{\mathrm{c}}$ near cloud tops during S1-S4, respectively.

\subsection{Evidence of the aerosol indirect effect}

$N_{\mathrm{c}}$ and $R_{\mathrm{e}}$ were compared between sawtooth maneuvers, and the differences reported hereafter refer to $95 \%$ confidence intervals for the difference in the variable means (based on a two-sample $t$ test, $p<0.02$ ). Between the contact profiles, S2 had significantly higher $N_{\mathrm{c}}$ (differences of 37 to $56 \mathrm{~cm}^{-3}$ ) compared to S3. This was despite having statistically insignificant differences in below-cloud $N_{\mathrm{a}}$, a greater fractional decrease in median $N_{\mathrm{c}}$ near cloud top compared to S3, and greater entrainment mixing (lower LWC / aLWC). S2 had significantly higher above-cloud $N_{\mathrm{a}}$ compared to $\mathrm{S} 3$ and the mixing of above-cloud air with high $N_{\mathrm{a}}$ likely resulted in droplet nucleation above cloud base, where the median $N_{\mathrm{c}}$ for S2 increased from 169 to $220 \mathrm{~cm}^{-3}$ over $Z_{\mathrm{N}}=0.25$ to 0.75 . Between the separated profiles, $\mathrm{S} 1$ had significantly higher $N_{\mathrm{c}}$ (differences of 108 to $126 \mathrm{~cm}^{-3}$ ), which could be attributed to significantly higher above-cloud $N_{\mathrm{a}}$ and greater entrainment mixing during S1 compared to S4. However, these differences could also be due to the meteorological differences at their sampling locations (lower boundary layer height, RH, and $500 \mathrm{mb}$ geopotential height for $\mathrm{S} 4$ along with a smaller decrease in $T$ and $q_{T}$ across cloud tops) or the significantly higher below-cloud $N_{\mathrm{a}}$ for $\mathrm{S} 1$ compared to $\mathrm{S} 4$.

Contact profiles had significantly higher $N_{\mathrm{c}}$ (differences of 45 to $61 \mathrm{~cm}^{-3}$ ) and lower $R_{\mathrm{e}}$ (differences of 1.4 to $2.0 \mu \mathrm{m}$ ) compared to separated profiles. Contact profiles also had significantly higher above-cloud $N_{\mathrm{a}}$ and greater entrainment mixing in the cloud layer (lower LWC/aLWC). These microphysical changes would also impact cloud reflectance (Twomey, 1991) as seen by the significantly higher cloud optical thickness $(\tau)$ of contact profiles compared to separated profiles (differences of 2.5 to 8.2). The increase in $\tau$ and the cloud reflectance provides observational evidence of the aerosol indirect effect over the Southeast Atlantic due to contact between above-cloud BBAs and the stratocumulus clouds.

However, contact profiles also had significantly higher below-cloud $N_{\mathrm{a}}$ (differences of 145 to $190 \mathrm{~cm}^{-3}$ ), which contribute to the higher $N_{\mathrm{c}}$ relative to separated profiles. Therefore, a statistical analysis was conducted with a larger number of profiles in an attempt to attribute these differences in $N_{\mathrm{c}}$ and $R_{\mathrm{e}}$ to the vertical distance between the above-cloud BBA layer and cloud tops. Building on this case study, 71 cloud profiles flown on six flights between 6 and 25 September 2016 were examined, and the impact of abovecloud BBAs on the free-tropospheric humidity and buoyancy across cloud tops was explored. Sixty-one contact and separated profiles were further classified as low- $N_{\mathrm{a}}$ or high- $N_{\mathrm{a}}$ profiles based on the below-cloud $N_{\mathrm{a}}$. This was done to quantify the differences in $N_{\mathrm{c}}$ and $R_{\mathrm{e}}$ between contact and separated profiles within boundary layers with similar belowcloud $N_{\mathrm{a}}$.

\section{Statistical analysis}

\subsection{Meteorological conditions and above-cloud aerosols}

Six flights (including PRF5) are included in the statistical analysis. On 10, 12, and 25 September, the P-3 took off from Walvis Bay, Namibia $\left(23^{\circ} \mathrm{S}, 14.6^{\circ} \mathrm{E}\right)$, and flew northwest from $23^{\circ} \mathrm{S}, 13.5^{\circ} \mathrm{E}$ toward $10^{\circ} \mathrm{S}, 0^{\circ} \mathrm{E}$, returning along the same track (Fig. 8). Different tracks were followed on 6, 14, and 20 September, which included meridional legs along 9, 7.5 and $9^{\circ} \mathrm{E}$, and 9 and $10.5^{\circ} \mathrm{E}$, respectively. Meteorological conditions on 10,12, and 14 September were similar to the conditions described for the case study. South-southeasterly surface winds were associated with a surface low-pressure system over Africa. The surface wind speeds varied between 
Table 4. The range of time, latitude, longitude, above-cloud AOD, and cloud-top height $\left(Z_{\mathrm{T}}\right)$ for cloud profiles flown during the six flights. The lowest altitude where above-cloud $N_{\mathrm{a}}>500 \mathrm{~cm}^{-3}$ occurred during the flight $\left(Z_{500}\right)$ is in the far-right column.

\begin{tabular}{lrrrrrr}
\hline Date & Time $(\mathrm{UTC})$ & Latitude $\left({ }^{\circ} \mathrm{S}\right)$ & Longitude $\left({ }^{\circ} \mathrm{E}\right)$ & $\mathrm{AOD}$ & $Z_{T}(\mathrm{~m})$ & $Z_{500}(\mathrm{~m})$ \\
\hline 6 Sep & $08: 46-12: 35$ & $10.2-19.7$ & $9.0-11.9$ & $0.27-0.49$ & $359-1002$ & 680 \\
10 Sep & $09: 09-12: 36$ & $14.1-18.7$ & $4.0-8.6$ & $0.21-0.29$ & $990-1201$ & 1800 \\
12 Sep & $11: 16-12: 26$ & $9.7-12.9$ & $-0.3-3.0$ & $0.25-0.29$ & $1146-1226$ & 1200 \\
14 Sep & $09: 36-14: 16$ & $16.4-18.1$ & $7.5-9.0$ & $0.31-0.32$ & $635-824$ & 2350 \\
20 Sep & $08: 44-13: 11$ & $15.7-17.3$ & $8.9-10.5$ & $0.42-0.56$ & $432-636$ & 600 \\
25 Sep & $10: 59-13: 51$ & $10.9-14.3$ & $0.8-4.3$ & $0.27-0.38$ & $729-1124$ & 1170 \\
\hline
\end{tabular}

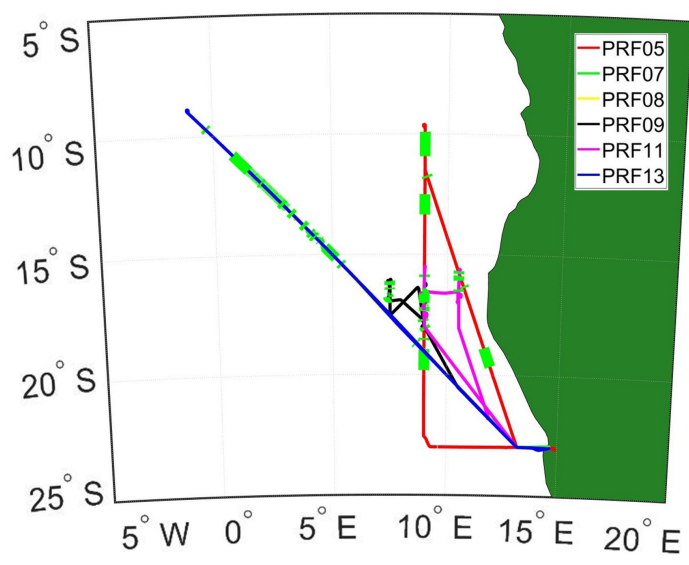

Figure 8. Flight tracks from PRFs 5, 7, 8, 9, 11, and 12 flown on $6,10,12,14,20$, and 25 September 2016 with green segments indicating location of cloud profiles (flight tracks from PRFs 7 and 8 coincide with PRF13 and hence are not visible).

5 and $10 \mathrm{~ms}^{-1}$ depending on the pressure gradient between the continental low and a surface high toward the southwest. A region of $925 \mathrm{mb} \mathrm{RH}<60 \%$ persisted along the coast due to dry-air advection from Africa. A different meteorological setup on 20 September had westerly surface winds and easterly winds at $925 \mathrm{mb}$. The aerosol plume was sampled immediately above the boundary layer $(600 \mathrm{~m})$ as warm surface air was overlaid by drier, polluted air from the continent. The continental surface low was located farther south on 25 September compared to other flight days with the region of low $925 \mathrm{mb} \mathrm{RH}$ to the south of the flight track. The study region had $\mathrm{RH}>60 \%$ with south-southeasterly surface winds and southerly $925 \mathrm{mb}$ winds. The BBA layer with above-cloud $N_{\mathrm{a}}>500 \mathrm{~cm}^{-3}$ was sampled during each flight with variability in its vertical location (Table 4). Only separated profiles were flown on 10 and 14 September (Table 2), when the BBA layer and cloud tops were separated by over 600 and $1500 \mathrm{~m}$, respectively (Table 4). On 12 September, profile 1 (P1) had $N_{\mathrm{a}}>500 \mathrm{~cm}^{-3}$ within 75 above cloud tops and was classified as a contact profile, while $\mathrm{P} 2$ and $\mathrm{S} 1$ were classified as separated profiles. On 20 September, each profile had above-cloud AOD > 0.4 and was classified as a contact profile. On 25 September, the profiles had above-cloud

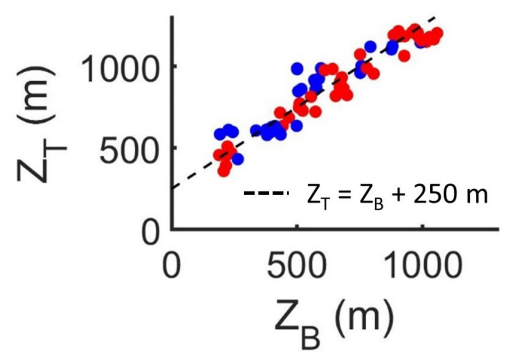

Figure 9. Cloud base and top heights for contact (blue) and separated (red) profiles flown during the six PRFs.

AOD $>0.27$, and each profile (except from a sawtooth near $\left.11^{\circ} \mathrm{S}, 1^{\circ} \mathrm{E}\right)$ was classified as a contact profile.

\section{2 $N_{\mathrm{c}}, R_{\mathrm{e}}$, and $\mathrm{LWC}$ for contact and separated profiles}

Since clouds sampled on different flight days had variable $Z_{\mathrm{B}}$ and $Z_{\mathrm{T}}$ (Fig. 9), vertical profiles of $N_{\mathrm{c}}, R_{\mathrm{e}}$, and LWC from the contact and separated profiles were compared as a function of $Z_{\mathrm{N}}$. The frequency distributions of $N_{\mathrm{c}}, R_{\mathrm{e}}$, and LWC as a function of $Z_{\mathrm{N}}$ are examined in Fig. 10 using violin plots (Hintze and Nelson, 1998; Wang et al., 2020), where the width of the shaded area represents the proportion of data there. The average $N_{\mathrm{c}}$ for contact profiles was significantly higher than the average $N_{\mathrm{c}}$ for separated profiles (differences of 60 to $68 \mathrm{~cm}^{-3}$ ). During separated profiles, the median $N_{\mathrm{c}}$ had little variability up to $Z_{\mathrm{N}}=0.75\left(114\right.$ to $\left.122 \mathrm{~cm}^{-3}\right)$ and decreased thereafter with $Z_{\mathrm{N}}$ to $73 \mathrm{~cm}^{-3}$ due to droplet evaporation (Fig. 10a). During contact profiles, the median $N_{\mathrm{c}}$ decreased slightly up to $Z_{\mathrm{N}}=0.25\left(183\right.$ to $\left.174 \mathrm{~cm}^{-3}\right)$, increased to $214 \mathrm{~cm}^{-3}$ at $Z_{\mathrm{N}}=0.75$, and decreased near cloud top to $157 \mathrm{~cm}^{-3}$ due to droplet evaporation. Contact profiles had significantly lower $R_{\mathrm{e}}$ than the separated profiles (differences of 1.1 to $1.3 \mu \mathrm{m}$ ), and the median $R_{\mathrm{e}}$ increased with $Z_{\mathrm{N}}$ from 4.9 to $7.0 \mu \mathrm{m}$ for contact and from 6.6 to $8.6 \mu \mathrm{m}$ for separated profiles (Fig. 10b). The differences in $R_{\mathrm{e}}$ were likely due to the significantly lower drizzle concentrations for contact profiles (differences of 5 to $20 \mathrm{~L}^{-1}$ ).

The average LWC for contact and separated profiles were within $0.01 \mathrm{~g} \mathrm{~m}^{-3}$, and the median LWC increased with $Z_{\mathrm{N}}$ to $0.23 \mathrm{~g} \mathrm{~m}^{-3}$ at $Z_{\mathrm{N}}=0.85$ for contact and $0.21 \mathrm{~g} \mathrm{~m}^{-3}$ at 

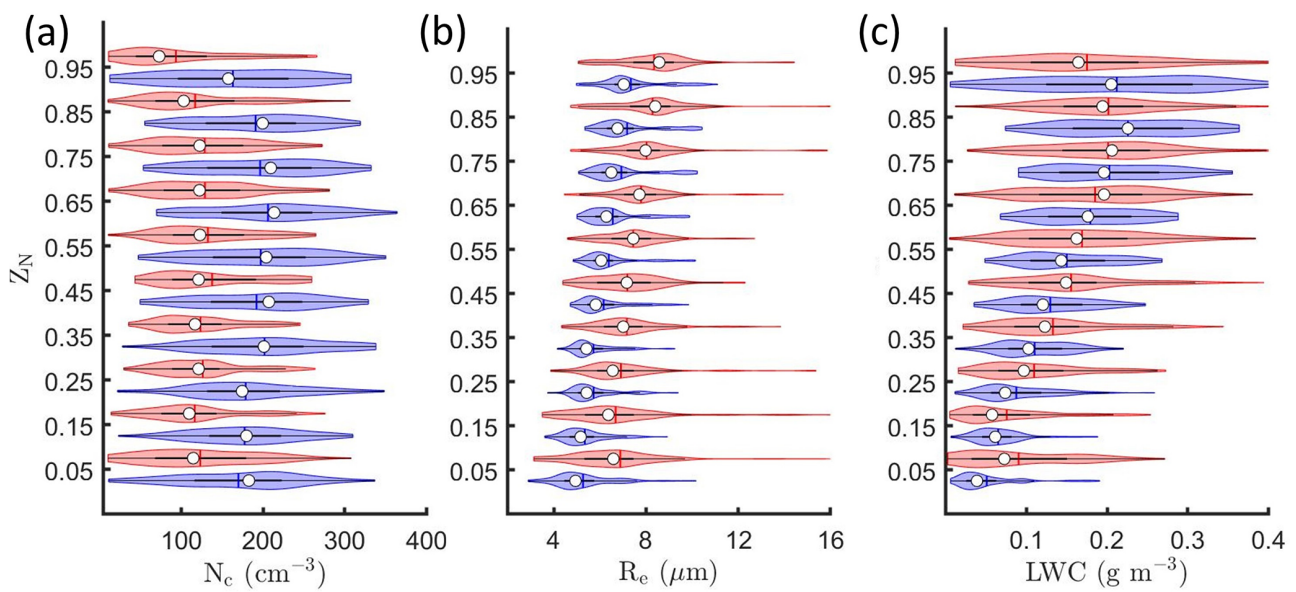

Figure 10. Kernel density estimates (indicated by the width of shaded area) and boxplots showing the 25th (Q1), 50th (white point), and 75th (Q3) percentile for (a) $N_{\mathrm{c}}$, (b) $R_{\mathrm{e}}$, and (c) LWC as a function of $Z_{\mathrm{N}}$ for contact (blue) and separated (red) profiles.

$Z_{\mathrm{N}}=0.75$ for separated profiles (Fig. 10c). Contact profiles had lower LWC / aLWC in the cloud layer (0.45) compared to separated profiles ( 0.57$)$, which suggests there was greater entrainment mixing during contact profiles, on average. However, droplet evaporation near cloud top had a stronger impact on separated profiles as the median LWC decreased to $0.16 \mathrm{~g} \mathrm{~m}^{-3}$ for separated and $0.20 \mathrm{~g} \mathrm{~m}^{-3}$ for contact profiles (Fig. 10c). Separated profiles had a greater decrease in LWC/aLWC near cloud top (0.41 to 0.26) compared to contact profiles $(0.38$ to 0.30$)$ and greater fractional decreases in median $N_{\mathrm{c}}$ and LWC (40 and $16 \%$ ) compared to contact profiles ( 25 and $9 \%$ ). The stronger impact of droplet evaporation during separated profiles contributed to the differences between $N_{\mathrm{c}}$ for contact and separated profiles.

\subsection{Cloud-top evaporative cooling}

Buoyancy and humidity across cloud tops were determined to explore the cloud-top entrainment mechanisms resulting in the differential impact of droplet evaporation for these profiles. Cloud-top instability is the dominant source of turbulence in stratocumulus, with evaporative cooling being a key driver of instability (Mellado, 2017). Recent studies have shown there is strong correlation between above-cloud AOD and water vapor within air masses originating from the African continent (Deaconu et al., 2019; Pistone et al., 2021). Longwave cooling by water vapor within the BBA layer leads to decreased cloud-top cooling, and cloud-top dynamics are influenced by distinct radiative contributions from water vapor and absorbing aerosols. Evaporative cooling in a mixture of dry and cloudy air near cloud top generates negatively buoyant air mixtures, which further enhances mixing and leads to an entrainment feedback called cloud top entrainment instability, or CTEI (Kuo and Schubert, 1988). Under such conditions, negative buoyancy leads to an unstable feedback, unlike the conventional association of negative buoyancy with atmospheric stability. The critical condition for cloud-top stability is given by Kuo and Schubert (1988) as

$\Delta \theta_{\mathrm{e}}>k\left(\frac{L_{\mathrm{v}}}{C_{p}}\right) \Delta q_{T}$

where $k$ is the CTEI parameter, $\theta_{\mathrm{e}}$ is the equivalent potential temperature, $L_{\mathrm{v}}$ is the latent heat of vaporization, and $C_{p}$ is the specific heat capacity of air at constant pressure. The $\Delta$ operator represents gradients across the cloud top, defined here as the difference between $\theta_{\mathrm{e}}$ (or $q_{T}$ ) measured $100 \mathrm{~m}$ above cloud top and the vertical average of $\theta_{\mathrm{e}}$ (or $q_{T}$ ) over the top $100 \mathrm{~m}$ of the profile. Following Eq. (13) from Kuo and Schubert (1988), $k>0.23$ indicates negative buoyancy across cloud tops. Water vapor mixing ratio measured by the chilled-mirror hygrometer was used to calculate $\theta_{\mathrm{e}}$ and $q_{T}$. Since lower $\Delta q_{T}$ was sampled during descents into cloud due to condensation on the hygrometer, $k$ values for descents were determined to be measurement artifacts and not usable here.

All separated profiles (except PRF5 S1-3 and S4-1, S43 , and S4-5) laid within the region of cloud-top instability $(k>0.23)$ on a $\Delta \theta_{\mathrm{e}}-\Delta q_{T}$ plane (Fig. 11) and showed negative buoyancy across cloud tops. During PRF5 S1-3, low $\Delta \theta_{\mathrm{e}}$ was sampled due to higher above-cloud humidity associated with the presence of $N_{\mathrm{a}}>100 \mathrm{~cm}^{-3}$ within $50 \mathrm{~m}$ above cloud tops. During PRF5 S4, a weak cloud-top inversion led to positive $\Delta \theta_{\mathrm{e}}$ and $\Delta q_{T}<-2 \mathrm{~g} \mathrm{~kg}^{-1}$ (Fig. 7). For the remaining separated profiles, negative buoyancy across cloud tops led to forced descent of dry free-tropospheric air into the clouds. Since the free-tropospheric air was warmer and drier than the cloudy air, droplet evaporation led to the decreases in median $N_{\mathrm{c}}$ and LWC near cloud top. The positive evaporative cooling feedback and greater $\Delta q_{T}$ compared to contact profiles (Fig. 11) explain the stronger impact of droplet evaporation on median $N_{\mathrm{c}}$ and LWC for separated profiles. 


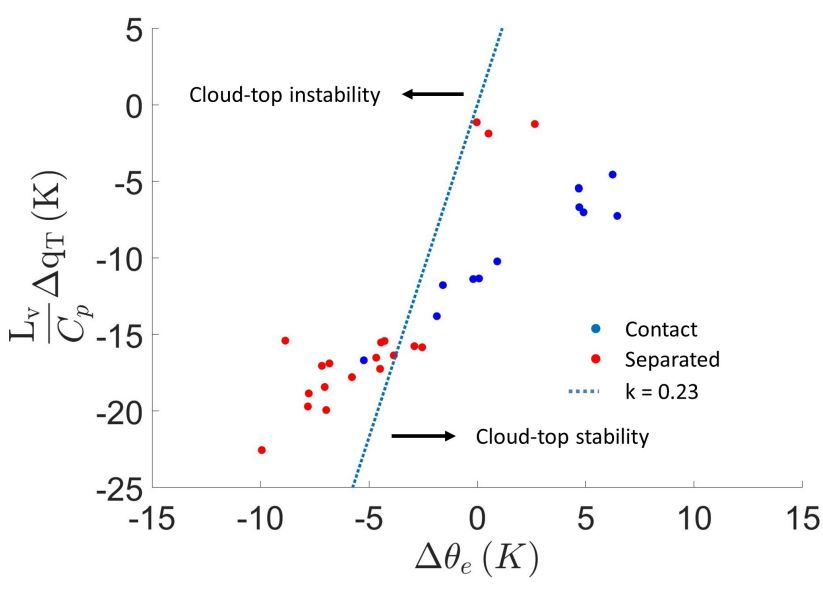

Figure 11. Difference between equivalent potential temperature $\left(\theta_{\mathrm{e}}\right)$ and total water mixing ratio $\left(q_{T}\right)$ measured within cloud and $100 \mathrm{~m}$ above cloud top for contact (blue) and separated (red) profiles (only ascents through cloud shown).

While evaporative cooling triggered the CTEI feedback, the clouds persisted, consistent with cloud-top radiative cooling or surface evaporation leading to boundary layer moistening (Lock, 2009; Mellado, 2017).

All contact profiles (except PRF13 S1-3) laid within the region of cloud-top stability and showed positive buoyancy across cloud tops. Entrainment mixing for these profiles likely occurred when the clouds penetrated the inversion. This is consistent with significantly higher average $H$ $(267 \mathrm{~m})$ for contact profiles compared to separated profiles $(213 \mathrm{~m})$. Braun et al. (2018) found a negative correlation between $H$ and adiabaticity (ratio of the measured and the adiabatic liquid water path), which is consistent with contact profiles having lower LWC/ aLWC and higher $H$ compared to separated profiles. In the presence of above-cloud BBAs, the above-cloud air was more humid, and the above-cloud $N_{\mathrm{a}}$ was significantly higher compared to separated profiles (differences of 768 to $831 \mathrm{~cm}^{-3}$ ). Contact profiles had greater entrainment mixing compared to separated profiles, and the median $N_{\mathrm{c}}$ increased with height over $Z_{\mathrm{N}}=0.25$ to 0.75 . It is likely the entrainment of BBAs into clouds resulted in additional droplet nucleation over these $Z_{N}$ levels. Therefore, weaker droplet evaporation near cloud top and additional droplet nucleation above cloud base in the presence of abovecloud BBAs likely contributed to the differences between $N_{\mathrm{c}}$ for contact and separated profiles.

\section{4 $N_{\mathrm{c}}, \boldsymbol{R}_{\mathrm{e}}$, and LWC in boundary layers with similar $N_{\mathrm{a}}$}

Contact profiles had significantly higher below-cloud $N_{\mathrm{a}}$ (differences of 93 to $115 \mathrm{~cm}^{-3}$ ) and below-cloud CO (differences of 13 to $16 \mathrm{ppb}$ ) in addition to higher above-cloud $N_{\mathrm{a}}$ (differences of 768 to $831 \mathrm{~cm}^{-3}$ ) compared to separated profiles. Enhanced aerosol loading within the boundary layer is consistent with BBAs immediately above cloud tops entraining into the cloud layer and polluting the boundary layer. This is consistent with higher above-cloud CO (240 ppb) sampled for contact profiles with below-cloud $\mathrm{CO}>100 \mathrm{ppb}$ compared to above-cloud CO (104 ppb) for profiles with below-cloud $\mathrm{CO}<100 \mathrm{ppb}$. The correlations between aboveand below-cloud aerosols could be partly due to the history of entrainment mixing between free-tropospheric and boundary layer air masses (Diamond et al., 2018). To investigate the contribution of below-cloud $N_{\mathrm{a}}$ relative to the impact of above-cloud BBAs on cloud properties, 28 contact and 33 separated profiles were classified into four new regimes defined as follows: contact high $N_{\mathrm{a}}(\mathrm{C}-\mathrm{H})$, separated high $N_{\mathrm{a}}(\mathrm{S}-\mathrm{H})$, contact low $N_{\mathrm{a}}(\mathrm{C}-\mathrm{L})$, and separated low $N_{\mathrm{a}}$ (S-L), where high- and low- $N_{\mathrm{a}}$ boundary layers were separated using a threshold concentration of $350 \mathrm{~cm}^{-3}$. Cloud microphysical properties and above- and below-cloud $N_{\mathrm{a}}$ were compared between $20 \mathrm{C}-\mathrm{H}$ and $11 \mathrm{~S}-\mathrm{H}$ profiles and between $8 \mathrm{C}-\mathrm{L}$ and $22 \mathrm{~S}$-L profiles (Table 5) to compare contact and separated profiles with minor differences in below-cloud $N_{\mathrm{a}}$.

Within low- $N_{\mathrm{a}}$ boundary layers, C-L and S-L profiles had insignificant differences in below-cloud $N_{\mathrm{a}}$ despite significantly higher above-cloud $N_{\mathrm{a}}$ for C-L profiles (differences of 592 to $669 \mathrm{~cm}^{-3}$ ), higher $N_{\mathrm{c}}$ (differences of 22.8 to $34.9 \mathrm{~cm}^{-3}$ ), and lower $R_{\mathrm{e}}$ (differences of 0.5 to $1.0 \mu \mathrm{m}$ ) compared to S-L profiles. Within high- $N_{\mathrm{a}}$ boundary layers, C-H profiles had significantly higher below-cloud $N_{\mathrm{a}}$ compared to S-H profiles (differences of 39.1 to $70.5 \mathrm{~cm}^{-3}$ ), but the differences were much smaller than those in the abovecloud $N_{\mathrm{a}}$ (differences of 738 to $884 \mathrm{~cm}^{-3}$ ). Further, the C-H profiles had significantly higher $N_{\mathrm{c}}$ (differences of 75.5 to $88.5 \mathrm{~cm}^{-3}$ ) and lower $R_{\mathrm{e}}$ (differences of 1.1 to $1.3 \mu \mathrm{m}$ ) than the $\mathrm{S}-\mathrm{H}$ profiles. Previous studies have argued the changes in $N_{\mathrm{c}}$ due to the impact of BBAs are more strongly correlated with below-cloud $N_{\mathrm{a}}$ compared to above-cloud $N_{\mathrm{a}}$ (Diamond et al., 2018; Mardi et al., 2019). However, these results suggest that, although the differences in $N_{\mathrm{c}}$ were lower than the differences in above-cloud $N_{\mathrm{a}}$, significant changes in $N_{\mathrm{c}}$ and $R_{\mathrm{e}}$ were associated with contact with above-cloud BBAs, and these changes were independent of the below-cloud aerosol loading.

Vertical profiles of $N_{\mathrm{c}}, R_{\mathrm{e}}$, and LWC are examined (Fig. 12) to further investigate the microphysical changes due to contact with above-cloud BBAs. Within low- $N_{\mathrm{a}}$ boundary layers, there were minor deviations in $N_{\mathrm{c}}$ with $Z_{\mathrm{N}}$ up to $Z_{N}=0.75$ (Fig. 12a). Over the top $20 \%$ of the cloud layer, S-L profiles had a decrease in median $N_{\mathrm{c}}\left(32 \mathrm{~cm}^{-3}\right)$, with a smaller change for C-L profiles $\left(8 \mathrm{~cm}^{-3}\right)$ over the same levels. There was also a weaker decrease in water vapor mixing ratio across cloud tops for contact profiles. Thus, cloudtop entrainment of more humid air likely occurred for the C-L profiles. This is consistent with higher median $R_{\mathrm{e}}$ and LWC over $Z_{\mathrm{N}}=0.75$ to 0.95 for C-L profiles compared to $\mathrm{S}$ $\mathrm{L}$ profiles despite having lower $R_{\mathrm{e}}$ and LWC closer to cloud base (Fig. 12b and c). Thus, the microphysical differences 
Table 5. Aerosol and cloud properties were averaged across all contact and separated profiles flown in low- $N_{\mathrm{a}}$ and-high $N_{\mathrm{a}}$ boundary layers. These averages were compared between contact and separated profiles. The values listed below represent the $95 \%$ confidence intervals (from a two-sample $t$ test) when the differences were statistically significant. Positive values indicate the average for contact profiles was higher, and "insignificant" denotes the differences were statistically insignificant.

\begin{tabular}{llllll}
\hline $\begin{array}{l}\text { Maximum below-cloud } N_{\mathrm{a}} \\
\left(\mathrm{cm}^{-3}\right)\end{array}$ & $\begin{array}{l}\text { Below-cloud } N_{\mathrm{a}} \\
\left(\mathrm{cm}^{-3}\right)\end{array}$ & $\begin{array}{l}\text { Above-cloud } N_{\mathrm{a}} \\
\left(\mathrm{cm}^{-3}\right)\end{array}$ & $\begin{array}{l}N_{\mathrm{c}} \\
\left(\mathrm{cm}^{-3}\right)\end{array}$ & $\begin{array}{l}R_{\mathrm{e}} \\
(\mu \mathrm{m})\end{array}$ & $\begin{array}{l}\mathrm{LWC} \\
\left(\mathrm{g} \mathrm{m}^{-3}\right)\end{array}$ \\
\hline Low $N_{\mathrm{a}}\left(<300 \mathrm{~cm}^{-3}\right)$ & $-1.3--26.5$ & $498.0-565.5$ & Insignificant & $-0.1--0.6$ & Insignificant \\
High $N_{\mathrm{a}}\left(>300 \mathrm{~cm}^{-3}\right)$ & $48.3-78.2$ & $746.7-884.3$ & $80.8-92.8$ & $-1.1--1.3$ & $0.0-0.02$ \\
Low $N_{\mathrm{a}}\left(<350 \mathrm{~cm}^{-3}\right)$ & Insignificant & $592.7-669.4$ & $22.8-34.9$ & $-0.3--0.9$ & $\begin{array}{l}\text { Insignificant } \\
\text { High } N_{\mathrm{a}}\left(>350 \mathrm{~cm}^{-3}\right)\end{array}$ \\
\hline
\end{tabular}
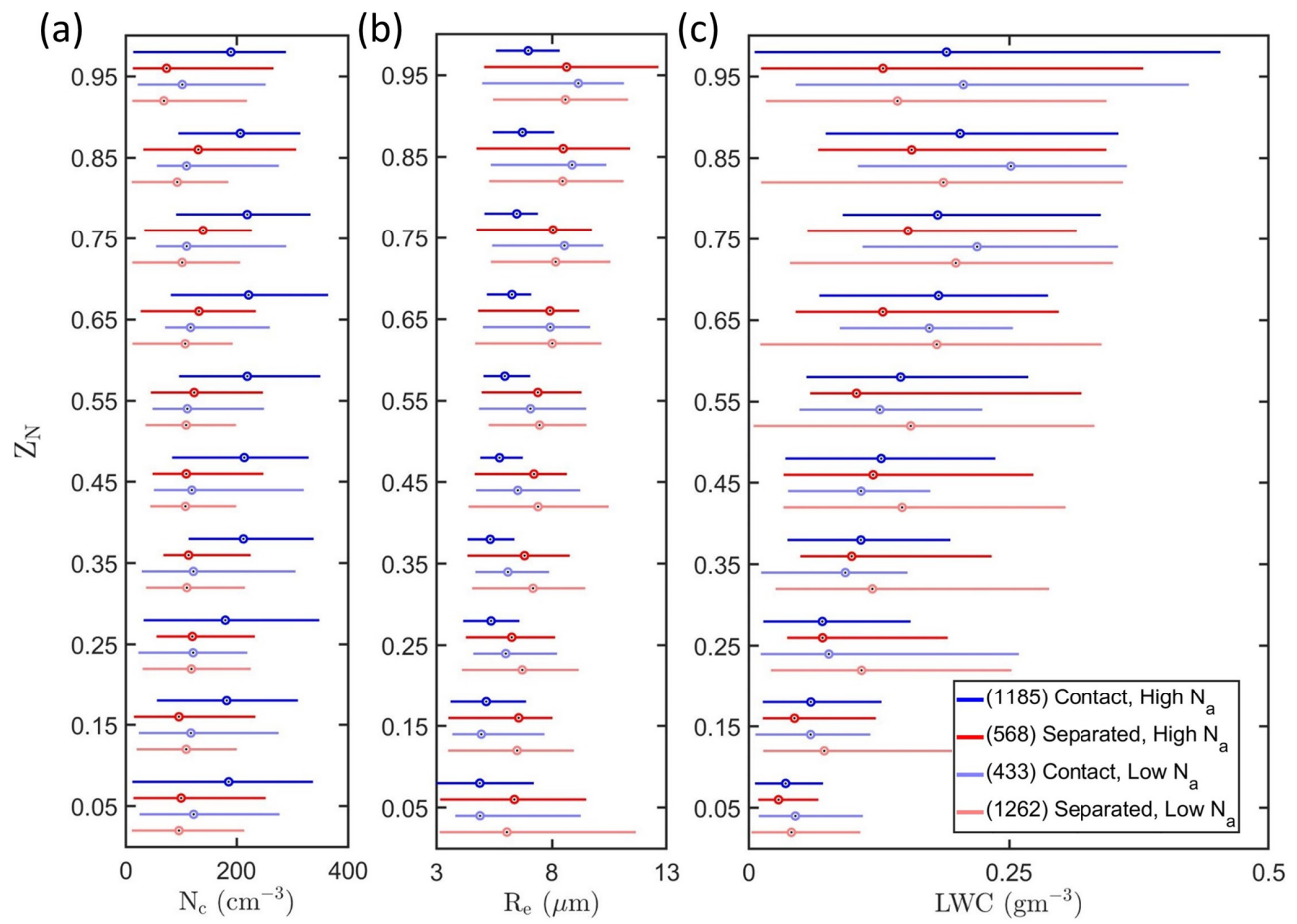

Figure 12. Boxplots representing vertical profiles of (a) $N_{\mathrm{c}}$, (b) $R_{\mathrm{e}}$, and (c) LWC as a function of $Z_{\mathrm{N}}$ for contact (blue) and separated (red) profiles within boundary layers with high $N_{\mathrm{a}}\left(>350 \mathrm{~cm}^{-3}\right)$ (darker) or low $N_{\mathrm{a}}\left(<350 \mathrm{~cm}^{-3}\right)$ (lighter). The number of $1 \mathrm{~Hz}$ measurements within each regime is listed within parentheses.

between contact and separated profiles within low- $N_{\mathrm{a}}$ boundary layers (where most separated profiles were sampled) are consistent with the processes of cloud-top entrainment and droplet evaporation.

The differences between below-cloud $N_{\mathrm{a}}$ for $\mathrm{C}-\mathrm{H}$ profiles and that for S-H profiles ( 39.1 to $70.5 \mathrm{~cm}^{-3}$ ) were lower than the corresponding differences in $N_{\mathrm{c}}\left(75.5\right.$ to $\left.88.4 \mathrm{~cm}^{-3}\right)$. C$\mathrm{H}$ profiles had significantly higher $N_{\mathrm{c}}$ and lower $R_{\mathrm{e}}$ compared to S-H profiles throughout the cloud layer (Fig. 12a and b). There was a significant increase in median $N_{\mathrm{c}}$ for C$\mathrm{H}$ profiles over $Z_{\mathrm{N}}=0.25$ to 0.75 , which was accompanied by higher median LWC for C-H profiles in the top half of the cloud layer. This is consistent with additional droplet nucleation above cloud base during $\mathrm{C}-\mathrm{H}$ profiles. Additionally, there was a stronger decrease in $N_{\mathrm{c}}$ near cloud top for $\mathrm{S}-\mathrm{H}$ profiles $\left(N_{\mathrm{c}}\right.$ decreased by $\left.66 \mathrm{~cm}^{-3}\right)$ compared to C-H profiles $\left(N_{\mathrm{c}}\right.$ decreased by $\left.29 \mathrm{~cm}^{-3}\right)$ likely due to cloud-top entrainment. It is difficult to separate the impact of changes in droplet nucleation on differences in $N_{\mathrm{c}}$ between C-H and S$\mathrm{H}$ profiles from the impact of changes in droplet evaporation due to cloud-top entrainment. Therefore, it is speculated the microphysical changes within high- $N_{\mathrm{a}}$ boundary layers were likely driven by the combination of higher below-cloud $N_{\mathrm{a}}$, potential droplet nucleation above cloud base, and weaker droplet evaporation near cloud tops in the presence of abovecloud BBAs. The sensitivity of these results to using different thresholds to locate BBAs (other than $500 \mathrm{~cm}^{-3}$ ), to define "separation" between the aerosol and cloud layers (other than 
$100 \mathrm{~m}$ ), and to define a "high- $N_{\mathrm{a}}$ boundary layer" (other than $350 \mathrm{~cm}^{-3}$ ) is discussed in Appendix A but does not affect the qualitative findings.

\section{Discussion}

The presence of water vapor and absorbing aerosols within the BBA layer can have distinct impacts on cloud-top cooling and cloud-top dynamics (Deaconu et al., 2019; Herbert et al., 2020; Kuo and Schubert, 1988). In the presence of above-cloud BBAs during ORACLES, the above-cloud air was more humid than in its absence, and cloud-top entrainment of free-tropospheric air with a higher water vapor mixing ratio likely contributed to the microphysical differences between contact and separated profiles, consistent with previous observations (Ackerman et al., 2004). Further, C-H profiles had significantly lower drizzle concentration compared to $\mathrm{S}-\mathrm{H}$ profiles (differences of 4 to $21 \mathrm{~L}^{-1}$ ), but C-L and S-L profiles had similar drizzle concentrations $\left(61\right.$ and $\left.62 \mathrm{~L}^{-1}\right)$. Research is ongoing to examine the changes in cloud and precipitation properties in different aerosol regimes since precipitation suppression could also impact below-cloud $N_{\mathrm{a}}$ through reduced aerosol scavenging by drizzle (Pennypacker et al., 2020).

Within polluted boundary layers, the below-cloud $N_{\mathrm{a}}$ was larger for instances of contact between above-cloud BBAs and cloud tops. It is speculated the increase in below-cloud $N_{\mathrm{a}}$ alone would be insufficient to cause the microphysical differences between contact and separated profiles, and this is particularly true for polluted boundary layers. The $N_{\mathrm{c}}$ also depends on other factors, including updraft strength and aerosol composition and hygroscopicity (Fuchs et al., 2018; Kacarab et al., 2020; Mardi et al., 2019). High-resolution modeling studies with bin-resolved microphysics are needed to examine cloud-top entrainment processes and investigate the relative impact of semidirect and indirect effects of BBAs on marine stratocumulus over the Southeast Atlantic. Additionally, aerosol-cloud-precipitation interactions must be examined under different aerosol and meteorological regimes to investigate the buffering effects of local meteorology and thermodynamic profiles associated with the absorbing aerosols (Deaconu et al., 2019; Diamond et al., 2018; Fuchs et al., 2018; Herbert et al., 2020; Sakaeda et al., 2011; Stevens and Feingold, 2009).

The changes in $N_{\mathrm{c}}, R_{\mathrm{e}}$, and drizzle concentration presented here could lead to aerosol-induced precipitation suppression and impact stratocumulus-to-cumulus transitions over the Southeast Atlantic (Yamaguchi et al., 2015; Zhou et al., 2017). Subsequently, changes in precipitation rate could affect the balance between aerosol scavenging and entrainment and modulate the reversible open-closed-cell transitions (Abel et al., 2020; Feingold et al., 2015). These processes would affect the cloud radiative forcing and the direct aerosol radiative forcing, which depends on the albedo of the underlying cloud layer (Cochrane et al., 2019). Research is ongoing to quantify precipitation susceptibility as a function of the vertical displacement of above-cloud absorbing aerosols from cloud tops. A larger dataset including additional ORACLES observations from August 2017 and October 2018 will allow evaluation of cloud and precipitation retrievals (Dzambo et al., 2019; Painemal et al., 2020) and investigations of aerosol-cloud-precipitation interactions over a broader range of environmental conditions. Better understanding of these processes will help reduce uncertainties in the estimates of cloud radiative effects due to changes in cloud cover and cloud reflectance (Albrecht, 1989; Twomey, 1974, 1991).

\section{Conclusions}

This study provides observational evidence of the aerosol indirect effect on marine stratocumulus cloud properties due to contact between above-cloud biomass burning aerosols and stratocumulus cloud tops over the Southeast Atlantic Ocean. Biomass burning aerosols overlay marine stratocumulus clouds there with variability in the vertical separation ( 0 to $2000 \mathrm{~m}$ ) between the aerosol layer and cloud tops. In situ measurements of cloud and aerosol properties from six research flights during the NASA ORACLES field campaign in September 2016 are presented. These observations suggest the presence of biomass burning aerosols immediately above cloud tops was associated with changes in vertical profiles of $N_{\mathrm{c}}, R_{\mathrm{e}}$, and LWC due to cloud-top entrainment and increases in the free-tropospheric temperature and humidity. Meteorological conditions and the vertical profiles of $N_{\mathrm{c}}, R_{\mathrm{e}}, \mathrm{LWC}$, and above- and below-cloud $N_{\mathrm{a}}$ are examined for a case study of 6 September 2016. Thinner clouds with lower cloud base and top heights were sampled closer to the coast due to lower relative humidity and boundary layer height compared to clouds sampled along $9^{\circ}$ E. For 33 cloud profiles, cloud-top entrainment deepened the boundary layer, decoupled the stratocumulus layer from the surface, and resulted in cumulus formation below the stratocumulus. The vertical profiles of cloud ( $N_{\mathrm{c}}, R_{\mathrm{e}}$, and LWC) and thermodynamic $\left(q_{T}\right.$ and $\left.T\right)$ properties sampled on 6 September 2016 were consistent with observations of stratocumulus-topped boundary layers capped by an inversion with warm, dry freetropospheric air above the clouds (Wood, 2012).

Above-cloud air masses originating from Africa were composed of biomass burning products (OA, $\mathrm{rBC}$, and $\mathrm{CO}$ ) with higher $N_{\mathrm{a}}$ compared to above-cloud air masses originating from the boundary layer over the Southeast Atlantic Ocean. Thirty contact profiles were flown, where the level of $N_{\mathrm{a}}>500 \mathrm{~cm}^{-3}$ was within $100 \mathrm{~m}$ above cloud tops, and 41 separated profiles were flown, where $N_{\mathrm{a}}>500 \mathrm{~cm}^{-3}$ was sampled at least $100 \mathrm{~m}$ above cloud tops. For contact profiles, the average $N_{\mathrm{c}}$ in the cloud layer was up to $68 \mathrm{~cm}^{-3}$ higher, the average $R_{\mathrm{e}}$ was up to $1.3 \mu \mathrm{m}$ lower, and the average LWC 
was within $0.01 \mathrm{~g} \mathrm{~m}^{-3}$ compared to separated profiles. During the contact profiles, $q_{T}$ decreased across cloud tops by up to $6 \mathrm{~g} \mathrm{~kg}^{-1}$. With positive buoyancy across cloud tops, mixing between free-tropospheric and cloudy air occurred when clouds penetrated the inversion and median $N_{\mathrm{c}}$ and LWC decreased by 25 and $9 \%$ near cloud tops due to droplet evaporation. The entrainment mixing of free-tropospheric air with $N_{\mathrm{a}}>500 \mathrm{~cm}^{-3}$ likely resulted in droplet nucleation above cloud base, and the median $N_{\mathrm{c}}$ for contact profiles increased within the middle of the cloud layer. During separated profiles, $q_{T}$ decreased across cloud tops by up to $9 \mathrm{~g} \mathrm{~kg}^{-1}$. With negative buoyancy across cloud tops, forced descent of drier free-tropospheric air into the clouds resulted in a positive feedback of evaporative cooling, and median $N_{\mathrm{c}}$ and LWC decreased by 30 and $16 \%$ due to droplet evaporation. The median $N_{\mathrm{c}}$ during separated profiles had little variability with height above cloud base before decreasing near cloud top due to droplet evaporation. Therefore, contact profiles had higher $N_{\mathrm{c}}$ due to a combination of weaker droplet evaporation near cloud tops and additional droplet nucleation above cloud base in the presence of above-cloud biomass burning aerosols.
Biomass burning aerosols located immediately above cloud top mixed into the cloud and polluted the boundary layer. During the case study, sawtooth maneuvers with contact profiles had higher below-cloud $\mathrm{rBC}$ and $\mathrm{CO}$ concentrations (by up to $60 \mathrm{~cm}^{-3}$ and $30 \mathrm{ppb}$ ) compared to maneuvers with separated profiles. Among the 71 profiles across six research flights, contact profiles had significantly higher below-cloud $\mathrm{CO}$ and $N_{\mathrm{a}}$ compared to separated profiles due to the contact between biomass burning aerosols and cloud tops. Twenty-eight contact and 33 separated profiles were further classified as contact high $N_{\mathrm{a}}(\mathrm{C}-\mathrm{H})$, contact low $N_{\mathrm{a}}$ (C-L), separated high $N_{\mathrm{a}}(\mathrm{S}-\mathrm{H})$, and separated low $N_{\mathrm{a}}$ (SL) to represent contact or separated profiles within high$N_{\mathrm{a}}\left(>350 \mathrm{~cm}^{-3}\right)$ or low- $N_{\mathrm{a}}\left(<350 \mathrm{~cm}^{-3}\right)$ boundary layers. C-L profiles had up to $34.9 \mathrm{~cm}^{-3}$ higher average $N_{\mathrm{c}}$ and up to $0.9 \mu \mathrm{m}$ lower average $R_{\mathrm{e}}$ compared to S-L profiles despite statistically insignificant differences between the below-cloud $N_{\mathrm{a}}$. C-H profiles had up to $70.5 \mathrm{~cm}^{-3}$ higher below-cloud $N_{\mathrm{a}}$, up to $88.4 \mathrm{~cm}^{-3}$ higher $N_{\mathrm{c}}$, and up to $1.6 \mu \mathrm{m}$ lower $R_{\mathrm{e}}$ compared to $\mathrm{S}-\mathrm{H}$ profiles. The differences between contact and separated profiles in low- $N_{\mathrm{a}}$ boundary layers were likely driven by weaker droplet evaporation in the presence of above-cloud biomass burning aerosols. Within high$N_{\mathrm{a}}$ boundary layers, the median $N_{\mathrm{c}}$ increased with height in the middle of the cloud layer, potentially due to droplet nucleation above cloud base. The differences between contact and separated profiles within high- $N_{\mathrm{a}}$ boundary layers were likely driven by a combination of higher below-cloud $N_{\mathrm{a}}$, droplet nucleation above cloud base, and weaker droplet evaporation in the presence of biomass burning aerosols above cloud tops. 


\section{Appendix A}

Cloud profiles were classified as contact or separated according to whether above-cloud $N_{\mathrm{a}}$ greater than $500 \mathrm{~cm}^{-3}$ was measured at a level within $100 \mathrm{~m}$ above cloud tops. The classification of cloud profiles remained unchanged when $N_{\mathrm{a}}=400 \mathrm{~cm}^{-3}$ instead of $N_{\mathrm{a}}=500 \mathrm{~cm}^{-3}$ was used to locate the aerosol layer. When the level of $N_{\mathrm{a}}=300 \mathrm{~cm}^{-3}$ was used, 3 of the 26 separated profiles (PRF5 S1, PRF5 P2, and PRF7 P6) switched to the contact regime. The qualitative results were unchanged as contact profiles had higher $N_{\mathrm{c}}$ (differences of 63 to $71 \mathrm{~cm}^{-3}$ ) and lower $R_{\mathrm{e}}$ (differences of 1.1 to $1.3 \mu \mathrm{m})$ compared to separated profiles. When a level of $N_{\mathrm{a}}=600 \mathrm{~cm}^{-3}$ was used, 2 of the 15 contact profiles (PRF5 P1 and P3) switched to the separated regime and contact profiles had higher $N_{\mathrm{c}}$ (differences of 59 to $67 \mathrm{~cm}^{-3}$ ) and lower $R_{\mathrm{e}}$ (differences of 1.0 to $1.2 \mu \mathrm{m}$ ). No additional changes were observed upon changing the definition of the BBA layer. Thus, the results obtained were robust as relates to this threshold.

A gap of $100 \mathrm{~m}$ was used to define separation between the BBAs and the clouds. When this gap was decreased to $50 \mathrm{~m}, 4$ of the 15 contact profiles (PRF5 P4, PRF8 P1, and PRF11 S1 and P6) switched to the separated regime and the contact regime had higher $N_{\mathrm{c}}$ (differences of 50 to $59 \mathrm{~cm}^{-3}$ ) and lower $R_{\mathrm{e}}$ (differences of 0.67 to $0.92 \mu \mathrm{m}$ ). There was no change in the profile classification when increasing the gap from $100 \mathrm{~m}$ to $200 \mathrm{~m}$. On increasing the gap to $300 \mathrm{~m}$, PRF5 S4 switched to the contact regime and contact profiles had higher $N_{\mathrm{c}}$ (differences of 36 to $45 \mathrm{~cm}^{-3}$ ) and lower $R_{\mathrm{e}}$ (differences of 0.4 to $0.6 \mu \mathrm{m}$ ). The same profile switches were observed when the definition of the gap was varied between 50 and $300 \mathrm{~m}$ for a threshold of above-cloud $N_{\mathrm{a}}=400 \mathrm{~cm}^{-3}$ to locate the BBA layer. Thus, the findings were robust as relates to the choice of these thresholds.
There were no profiles with maximum below-cloud $N_{\mathrm{a}}<100 \mathrm{~cm}^{-3}$, and only three contact profiles (with $1391 \mathrm{~Hz}$ measurements) had maximum below-cloud $N_{\mathrm{a}}<200 \mathrm{~cm}^{-3}$. A threshold of $300 \mathrm{~cm}^{-3}$ used to define a "high- $N_{\mathrm{a}}$ boundary layer", and cloud microphysical properties and above- and below-cloud $N_{\mathrm{a}}$ were compared between $22 \mathrm{C}-\mathrm{H}$ and $13 \mathrm{~S}-\mathrm{H}$ profiles and between $6 \mathrm{C}-\mathrm{L}$ and $20 \mathrm{~S}-$ L profiles (Table 5). Within low- $N_{\text {a }}$ boundary layers, C-L profiles had slightly lower below-cloud $N_{\mathrm{a}}$ (differences of 1.3 to $26.5 \mathrm{~cm}^{-3}$ ) and similar $N_{\mathrm{c}}$ (insignificant differences) compared to S-L profiles. All other comparisons between the four regimes were consistent with the discussion in Sect. 4.3, where a threshold of below-cloud $N_{\mathrm{a}}=350 \mathrm{~cm}^{-3}$ was used to define a "high- $N_{\mathrm{a}}$ boundary layer". When the threshold was increased to $400 \mathrm{~cm}^{-3}$ and $450 \mathrm{~cm}^{-3}$, the qualitative results were unchanged, and C-H (and C-L) profiles had significantly higher $N_{\mathrm{c}}$ and lower $R_{\mathrm{e}}$ compared to S-H (and S-L) profiles. Additionally, there were minor differences between $\mathrm{C}-\mathrm{H}$ and $\mathrm{C}-\mathrm{L}$ profiles and between S-H and S-L profiles for these thresholds. Thus, the findings are robust as relates to the choice of this threshold. 
Code availability. University of Illinois/Oklahoma Optical Array Probe (OAP) Processing Software is available at https://doi.org/10.5281/zenodo.1285969 (McFarquhar et al., 2018). The Airborne Data Processing and Analysis software package is available at https://zenodo.org/record/3733448 (Delene et al., 2020).

Data availability. All ORACLES 2016 in situ data used in this study are publicly available at https://doi.org/10.5067/Suborbital/ORACLES/P3/2016_V2

(ORACLES Science Team, 2020). This is a fixed-revision subset of the entire ORACLES mission dataset. It contains only the file revisions that were available on 27 May 2020.

Author contributions. SG and GMM conceived the study design and analysis. JRO'B, DJD, and SG processed the in situ cloud probe data. SG analyzed the data with inputs from GMM, JRO'B, and MRP. GMM, JR, and MRP acquired funding. SG, GMM, JRO'B, DJD, AD, JRP, JR, SEL, MSR, and KP collected data on board the NASA P-3. SG wrote the paper with reviews from co-authors.

Competing interests. The authors declare that they have no conflict of interest.

Special issue statement. This article is part of the special issue "New observations and related modelling studies of the aerosolcloud-climate system in the Southeast Atlantic and southern Africa regions (ACP/AMT inter-journal SI)". It is not associated with a conference.

Acknowledgements. The authors wish to acknowledge Yohei Shinozuka for compiling the merged instrument data files and the entire ORACLES science team for valuable discussions during data acquisition and analysis. We thank Rei Ueyama, Leonhard Pfister, and Ju-Mee Ryoo for creating figures obtained from https: //bocachica.arc.nasa.gov/ORACLES/ (last access: 22 March 2021). We would like to thank the NASA Ames Earth Science Project Office and the NASA P-3 flight and maintenance crew for the successful deployment. The authors gratefully acknowledge the NOAA Air Resources Laboratory (ARL) for the provision of the HYSPLIT transport and dispersion model and READY website (https://www.ready.noaa.gov, last access: 12 December 2017) used in this publication. Some of the computing for this project was performed at the OU Supercomputing Center for Education \& Research (OSCER) at the University of Oklahoma (OU).

Financial support. This research has been supported by NASA (grant no. 80NSSC18K0222). ORACLES is funded by NASA Earth Venture Suborbital-2 (grant no. NNH13ZDA001N-EVS2). Siddhant Gupta was supported by NASA headquarters under the NASA Earth and Space Science Fellowship (grant nos. NNX15AF93G and NNX16A018H).
Review statement. This paper was edited by Peter Knippertz and reviewed by Jonathan Taylor and two anonymous referees.

\section{References}

Abel, S. J., Barrett, P. A., Zuidema, P., Zhang, J., Christensen, M., Peers, F., Taylor, J. W., Crawford, I., Bower, K. N., and Flynn, M.: Open cells exhibit weaker entrainment of freetropospheric biomass burning aerosol into the south-east Atlantic boundary layer, Atmos. Chem. Phys., 20, 4059-4084, https://doi.org/10.5194/acp-20-4059-2020, 2020.

Ackerman, A. S., Toon, O. B., Stevens, D. E., Heymsfield, A. J., Ramanathan, V., and Welton, E. J.: Reduction of tropical cloudiness by soot, Science, 288, 1042-1047, 2000.

Ackerman, A. S., Kirkpatrick, M. P., Stevens, D. E., and Toon, O. B.: The impact of humidity above stratiform clouds on indirect climate forcing, Nature, 432, 1014-1017, 2004.

Adebiyi, A. A. and Zuidema, P.: The role of the southern African easterly jet in modifying the southeast Atlantic aerosol and cloud environments, Q. J. Roy. Meteor. Soc., 142, 1574-1589, https://doi.org/10.1002/qj.2765, 2016.

Albrecht, B.: Aerosols, Cloud Microphysics, and Fractional Cloudiness, Science, 245, 1227-1230, 1989.

Baumgardner, D., Jonsson, H., Dawson, W., Connor, D. O., and Newton, R.: The cloud, aerosol and precipitation spectrometer (CAPS): A new instrument for cloud investigations, Atmos. Res., 59, 59-60, 2001.

Baumgardner, D., Abel, S. J., Axisa, D., Cotton, R., Crosier, J., Field, P., Gurganus, C., Heymsfield, A., Korolev, A., Kraemer, M., Lawson, P., McFarquhar, G., Ulanowski, Z., and Um, J.: Cloud ice properties: in situ measurement challenges, Meteor. Mon., 58, 9.1-9.23, https://doi.org/10.1175/AMSMONOGRAPHS-D-16-0011.1, 2017.

Boucher, O., Randall, D., Artaxo, P., Bretherton, C., Feingold, G., Forster, P., Kerminen, V.-M., Kondo, Y., Liao, H., Lohmann, U., Rasch, P., Satheesh, S. K., Sherwood, S., Stevens, B., and Zhang, X. Y.: Clouds and Aerosols, in: Climate Change 2013: The Physical Science Basis, Contribution of Working Group I to the Fifth Assessment Report of the Intergovernmental Panel on Climate Change, edited by: Stocker, T. F., Qin, D., Plattner, G.-K., Tignor, M., Allen, S. K., Boschung, J., Nauels, A., Xia, Y., Bex, V., and Midgley, P. M., Cambridge University Press, Cambridge, UK and New York, NY, USA, 571-657, 2013.

Braun, R. A., Dadashazar, H., MacDonald, A. B., Crosbie, E., Jonsson, H. H., Woods, R. K., Flagan, R. C., Seinfeld, J. H., and Sorooshian, A.: Cloud Adiabaticity and Its Relationship to Marine Stratocumulus Characteristics Over the Northeast Pacific Ocean, J. Geophys. Res.-Atmos., 123, 13790-13806, https://doi.org/10.1029/2018JD029287, 2018.

Bretherton, C. S., Wood, R., George, R. C., Leon, D., Allen, G., and Zheng, X.: Southeast Pacific stratocumulus clouds, precipitation and boundary layer structure sampled along $20^{\circ} \mathrm{S}$ during VOCALS-REx, Atmos. Chem. Phys., 10, 10639-10654, https://doi.org/10.5194/acp-10-10639-2010, 2010.

Brioude, J., Cooper, O. R., Feingold, G., Trainer, M., Freitas, S. R., Kowal, D., Ayers, J. K., Prins, E., Minnis, P., McKeen, S. A., Frost, G. J., and Hsie, E.-Y.: Effect of biomass burning on ma- 
rine stratocumulus clouds off the California coast, Atmos. Chem. Phys., 9, 8841-8856, https://doi.org/10.5194/acp-9-8841-2009, 2009.

Cai, Y., Snider, J. R., and Wechsler, P.: Calibration of the passive cavity aerosol spectrometer probe for airborne determination of the size distribution, Atmos. Meas. Tech., 6, 2349-2358, https://doi.org/10.5194/amt-6-2349-2013, 2013.

Chand, D., Wood, R., Anderson, T. L., Satheesh, S. K., and Charlson, R. J.: Satellite-derived direct radiative effect of aerosols dependent on cloud cover, Nat. Geosci., 2, 181-184, 2009.

Coakley Jr., J. A. and Walsh, C. D.: Limits to the aerosol indirect radiative forcing derived from observations of ship tracks, J. Atmos. Sci., 59, 668-680, 2002.

Cochrane, S. P., Schmidt, K. S., Chen, H., Pilewskie, P., Kittelman, S., Redemann, J., LeBlanc, S., Pistone, K., Kacenelenbogen, M., Segal Rozenhaimer, M., Shinozuka, Y., Flynn, C., Platnick, S., Meyer, K., Ferrare, R., Burton, S., Hostetler, C., Howell, S., Freitag, S., Dobracki, A., and Doherty, S.: Above-cloud aerosol radiative effects based on ORACLES 2016 and ORACLES 2017 aircraft experiments, Atmos. Meas. Tech., 12, 65056528, https://doi.org/10.5194/amt-12-6505-2019, 2019.

Coddington, O. M., Pilewskie, P., Redemann, J., Platnick, S., Russell, P. B., Schmidt, K. S., Gore, W. J., Livingston, J., Wind, G., and Vukicevic, T.: Examining the impact of overlying aerosols on the retrieval of cloud optical properties from passive remote sensing, J. Geophys. Res., 115, D10211, https://doi.org/10.1029/2009JD012829, 2010.

Costantino, L. and Breon, F.-M.: Analysis of aerosol-cloud interaction from multi-sensor satellite observations, Geophys. Res. Lett., 37, L11801, https://doi.org/10.1029/2009GL041828, 2010.

Deaconu, L. T., Ferlay, N., Waquet, F., Peers, F., Thieuleux, F., and Goloub, P.: Satellite inference of water vapour and abovecloud aerosol combined effect on radiative budget and cloudtop processes in the southeastern Atlantic Ocean, Atmos. Chem. Phys., 19, 11613-11634, https://doi.org/10.5194/acp-19-116132019, 2019.

Delene, D. J.: Airborne Data Processing and Analysis Software Package, Earth Sci. Inform., 4, 29-44, 2011.

Delene, D. J., Skow, A., O'Brien, J., Gapp, N., Wagner, S., Hibert, K., Sand, K., and Sova, G.: Airborne Data Processing and Analysis Software Package (Version 3981), Zenodo, https://doi.org/10.5281/zenodo.3733448, 2020.

Devasthale, A. and Thomas, M. A.: A global survey of aerosol-liquid water cloud overlap based on four years of CALIPSO-CALIOP data, Atmos. Chem. Phys., 11, 1143-1154, https://doi.org/10.5194/acp-11-1143-2011, 2011.

Diamond, M. S., Dobracki, A., Freitag, S., Small Griswold, J. D., Heikkila, A., Howell, S. G., Kacarab, M. E., Podolske, J. R., Saide, P. E., and Wood, R.: Time-dependent entrainment of smoke presents an observational challenge for assessing aerosolcloud interactions over the southeast Atlantic Ocean, Atmos. Chem. Phys., 18, 14623-14636, https://doi.org/10.5194/acp-1814623-2018, 2018.

Drewnick, F., Hings, S., De Carlo, P., Jayne, J., Gonin, M., Fuhrer, K., Weimer, S., Jimenez, J., Demerjian, K., Borrmann, S., and Worsnop, D.: A new time-of-flight aerosol mass spectrometer (TOF-AMS) - Instrument description and first field deployment, Aerosol Sci. Tech., 39, 637-658, https://doi.org/10.1080/02786820500182040, 2005.
Dunagan, S. E., Johnson, R., Zavaleta, J., Russell, P. B., Schmid, B., Flynn, C., Redemann, J., Shinozuka, Y., Livingston, J., and Segal-Rosenhaimer, M.: Spectrometer for Sky-Scanning Sun-Tracking Atmospheric Research (4STAR): Instrument technology, Remote Sens., 5, 3872-3895, https://doi.org/10.3390/rs5083872, 2013.

Dzambo, A. M., L'Ecuyer, T., Sy, O. O., and Tanelli, S.: The Observed Structure and Precipitation Characteristics of Southeast Atlantic Stratocumulus from Airborne Radar During ORACLES 2016-17, J. Appl. Meteorol. Clim., 58, 2197-2215, https://doi.org/10.1175/jamc-d-19-0032.1, 2019.

Feingold, G., Koren, I., Yamaguchi, T., and Kazil, J.: On the reversibility of transitions between closed and open cellular convection, Atmos. Chem. Phys., 15, 7351-7367, https://doi.org/10.5194/acp-15-7351-2015, 2015.

Field, P., Heymsfield, A., and Bansemer, A.: Shattering and particle interarrival times measured by optical array probes in ice clouds, J. Atmos. Ocean. Tech., 23, 1357-1371, 2006.

Fuchs, J., Cermak, J., and Andersen, H.: Building a cloud in the southeast Atlantic: understanding low-cloud controls based on satellite observations with machine learning, Atmos. Chem. Phys., 18, 16537-16552, https://doi.org/10.5194/acp-18-165372018, 2018.

Hansen, J., Sato, M., and Ruedy, R.: Radiative forcing and climate response, J. Geophys. Res., 102, 6831-6864, 1997.

Haywood, J. M. and Shine, K. P.: Multi-spectral calculations of the radiative forcing of tropospheric sulfate and soot aerosols using a column model, Q. J. Roy. Meteor. Soc., 123, 1907-1930, 1997.

Haywood, J. M., Osborne, S. R., and Abel, S. J.: The effect of overlying absorbing aerosol layers on remote sensing retrievals of cloud effective radius and cloud optical depth, Q. J. Roy. Meteor. Soc., 130, 779-800, 2004.

Herbert, R. J., Bellouin, N., Highwood, E. J., and Hill, A. A.: Diurnal cycle of the semi-direct effect from a persistent absorbing aerosol layer over marine stratocumulus in large-eddy simulations, Atmos. Chem. Phys., 20, 1317-1340, https://doi.org/10.5194/acp-20-1317-2020, 2020.

Heymsfield, A. J. and McFarquhar, G. M.: Microphysics of INDOEX clean and polluted trade wind cumulus clouds, J. Geophys. Res., 106, 28653-28673, 2001.

Hill, A. A., Dobbie, S., and Yin, Y.: The impact of aerosols on nonprecipitating marine stratocumulus, I: Model description and prediction of the indirect effect, Q. J. Roy. Meteor. Soc., 134, 11431154, 2008.

Hintze, J. L. and Nelson, R. D.: Violin Plots: A Box Plot-Density Trace Synergism, Am. Stat., 52, 181-184, 1998.

Johnson, B. T., Shine, K. P., and Forster, P. M.: The semi-direct aerosol effect: Impact of absorbing aerosols on marine stratocumulus, Q. J. Roy. Meteor. Soc., 130, 1407-1422, 2004.

Johnson, B., Turnbull, K., Brown, P., Burgess, R., Dorsey, J., Baran, A. J., Webster, H., Haywood, J., Cotton, R., Ulanowski, Z., Hesse, E., Woolley, A., and Rosenberg, P.: In situ observations of volcanic ash clouds from the FAAM aircraft during the eruption of Eyjafjallajökull in 2010, J. Geophys. Res.-Atmos., 117, D00U24, https://doi.org/10.1029/2011JD016760, 2012.

Kacarab, M., Thornhill, K. L., Dobracki, A., Howell, S. G., O’Brien, J. R., Freitag, S., Poellot, M. R., Wood, R., Zuidema, P., Redemann, J., and Nenes, A.: Biomass burning aerosol as a modulator of the droplet number in the southeast Atlantic region, At- 
mos. Chem. Phys., 20, 3029-3040, https://doi.org/10.5194/acp20-3029-2020, 2020.

Keil, A. and Haywood, J. M.: Solar radiative forcing by biomass burning aerosol particles during SAFARI 2000: A case study based on measured aerosol and cloud properties, J. Geophys. Res., 108, 8467, https://doi.org/10.1029/2002JD002315, 2003.

King, W. D., Parkin, D. A., and Handsworth, R. J.: A hot-wire liquid water device having fully calculable response characteristics, J. Appl. Meteorol., 17, 1809-1813, https://doi.org/10.1175/15200450(1978)017<1809:AHWLWD>2.0.CO;2, 1978.

Klein, S. A. and Hartmann, D. L.: The seasonal cycle of low stratiform clouds, J. Climate, 6, 1587-1606, 1993.

Korolev, A.: Reconstruction of the sizes of spherical particles from their shadow images. Part I: Theoretical considerations, J. Atmos. Ocean. Tech., 24, 376-389, 2007.

Kuo, H. and Schubert, W.: Stability of cloud-topped boundary layers, Q. J. Roy. Meteor. Soc., 114, 887-916, 1988.

Lance, S., Brock, C. A., Rogers, D., and Gordon, J. A.: Water droplet calibration of the Cloud Droplet Probe (CDP) and in-flight performance in liquid, ice and mixed-phase clouds during ARCPAC, Atmos. Meas. Tech., 3, 1683-1706, https://doi.org/10.5194/amt-3-1683-2010, 2010.

Lawson, R. P., Stewart, R. E., and Angus, L. J.: Observations and numerical simulations of the origin and development of very large snowflakes, J. Atmos. Sci., 55, 3209-3229, 1998.

Lawson, R. P., O'Connor, D., Zmarzly, P., Weaver, K., Baker, B. A., Mo, Q., and Jonsson, H.: The 2D-S (Stereo) probe: Design and preliminary tests of a new airborne, high-speed, high-resolution imaging probe, J. Atmos. Ocean. Tech., 23, 1462-1477, 2006.

LeBlanc, S. E., Redemann, J., Flynn, C., Pistone, K., Kacenelenbogen, M., Segal-Rosenheimer, M., Shinozuka, Y., Dunagan, S., Dahlgren, R. P., Meyer, K., Podolske, J., Howell, S. G., Freitag, S., Small-Griswold, J., Holben, B., Diamond, M., Wood, R., Formenti, P., Piketh, S., Maggs-Kölling, G., Gerber, M., and Namwoonde, A.: Above-cloud aerosol optical depth from airborne observations in the southeast Atlantic, Atmos. Chem. Phys., 20, 1565-1590, https://doi.org/10.5194/acp-20-1565-2020, 2020.

Lock, A. P.: Factors influencing cloud area at the capping inversion for shallow cumulus clouds, Q. J. Roy. Meteor. Soc., 135, 941952, 2009.

Loeb, N. G., Wielicki, B. A., Doelling, D. R., Smith, G. L., Keyes, D. F., Kato, S., Manalo-Smith, N., and Wong, T.: Toward optimal closure of the Earth's Top-ofAtmosphere radiation budget, J. Climate, 22, 3, 748-766, https://doi.org/10.1175/2008JCLI2637.1, 2009.

Mardi, A. H., Dadashazar, H., MacDonald, A. B., Braun, R. A., Crosbie, E., Xian, P., Thorsen, T. J., Coggon, M. M., Fenn, M. A., Ferrare, R. A., Hair, J. W., Woods, R. K., Jonsson, H. H., Flagan, R. C., Seinfeld, J. H., and Sorooshian, A.: Biomass Burning Plumes in the Vicinity of the California Coast: Airborne Characterization of Physicochemical Properties, Heating Rates, and Spatiotemporal Features, J. Geophys. Res.-Atmos., 123, 13560 13582, https://doi.org/10.1029/2018JD029134, 2018.

Mardi, A. H., Dadashazar, H., MacDonald, A. B., Crosbie, E., Coggon, M. M., Aghdam, M. A., Woods, R. K., Jonsson, H. H., Flagan, R. C., Seinfeld, J. H., and Sorooshian, A.: Effects of Biomass Burning on Stratocumulus Droplet Characteristics, Drizzle Rate, and Composition, J. Geophys. Res.-Atmos., 124, 12301-12318, https://doi.org/10.1029/2019jd031159, 2019.
McFarquhar, G. M. and Wang, H.: Effects of Aerosols on Trade Wind Cumuli over the Indian Ocean: Model Simulations, Q. J. R. Meteor. Soc., 132, 821-843, 2006.

McFarquhar, G. M., Zhang, G., Poellot, M. R., Kok, G. L., McCoy, R., Tooman, T., Fridlind, A., and Heymsfield, A. J.: Ice properties of single-layer stratocumulus during the Mixed-Phase Arctic Cloud Experiment: 1. Observations, J. Geophys. Res., 112, D24201, https://doi.org/10.1029/2007jd008633, 2007.

McFarquhar, G. M., Baumgardner, D., Bansemer, A., Abel, S. J., Crosier, J., French, J., Rosenberg, P., Korolev, A., Schwarzoenboeck, A., Leroy, D., Um, J., Wu, W., Heymsfield, A. J., Twohy, C., Detwiler, A., Field, P., Neumann, A., Cotton, R., Axisa, D., Dong, J., McFarquhar, G. M., Baumgardner, D., Bansemer, A., Abel, S. J., Crosier, J., French, J., Rosenberg, P., Korolev, A., Schwarzoenboeck, A., Leroy, D., Um, J., Wu, W., Heymsfield, A. J., Twohy, C., Detwiler, A., Field, P., Neumann, A., Cotton, R., Axisa, D., and Dong, J.: Processing of Ice Cloud In Situ Data Collected by Bulk Water, Scattering, and Imaging Probes: Fundamentals, Uncertainties, and Efforts toward Consistency, Meteor. Mon., 58, 11.1-11.33, https://doi.org/10.1175/AMSMONOGRAPHSD-16-0007.1, 2017.

McFarquhar, G. M., Finlon, J. A., Stechman, D. M., Wu, W., Jackson, R. C., and Freer, M.: University of Illinois/Oklahoma Optical Array Probe (OAP) Processing Software, https://doi.org/10.5281/zenodo.1285969, 2018.

Mellado, J. P.: Cloud-top entrainment in stratocumulus clouds, Annu. Rev. Fluid Mech., 49, 145-169, 2017.

Middlebrook, A. M., Bahreini, R., Jimenez, J. L., and Canagaratna, M. R.: Evaluation of composition-dependent collection efficiencies for the aerodyne aerosol mass spectrometer using field data, Aerosol Sci. Tech., 46, 258-271, https://doi.org/10.1080/02786826.2011.620041s, 2012.

Myhre, G., Shindell, D., Bréon, F.-M., Collins, W., Fuglestvedt, J., Huang, J., Koch, D., Lamarque, J.-F., Lee, D., Mendoza, B., Nakajima, T., Robock, A., Stephens, G., Takemura, T., and Zhang, H.: Anthropogenic and Natural Radiative Forcing, in: Climate Change 2013: The Physical Science Basis. Contribution of Working Group I to the Fifth Assessment Report of the Intergovernmental Panel on Climate Change, edited by: Stocker, T. F., Qin, D., Plattner, G.-K., Tignor, M., Allen, S. K., Boschung, J., Nauels, A., Xia, Y., Bex, V., and Midgley, P. M., Cambridge University Press, Cambridge, UK and New York, NY, USA, 571657, 2013.

ORACLES Science Team: Suite of Aerosol, Cloud, and Related Data Acquired Aboard P3 During ORACLES 2016, Version 2, NASA Ames Earth Science Project Office, https://doi.org/10.5067/Suborbital/ORACLES/P3/2016_V2, 2020.

Oreopoulos, L. and Rossow, W. B.: The cloud radiative effects of International Satellite Cloud Climatology Project weather states, J. Geophys. Res.-Atmos., 116, D12202, https://doi.org/10.1029/2010JD015472, 2011.

Painemal, D. and Zuidema, P.: Assessment of MODIS cloud effective radius and optical thickness retrievals over the Southeast $\mathrm{Pa}-$ cific with VOCALS-REx in situ measurements, J. Geophys. Res., 116, D24206, https://doi.org/10.1029/2011jd016155, 2011.

Painemal, D., Chang, F.-L., Ferrare, R., Burton, S., Li, Z., Smith Jr., W. L., Minnis, P., Feng, Y., and Clayton, M.: Reduc- 
ing uncertainties in satellite estimates of aerosol-cloud interactions over the subtropical ocean by integrating vertically resolved aerosol observations, Atmos. Chem. Phys., 20, 71677177, https://doi.org/10.5194/acp-20-7167-2020, 2020.

Pennypacker, S., Diamond, M., and Wood, R.: Ultra-clean and smoky marine boundary layers frequently occur in the same season over the southeast Atlantic, Atmos. Chem. Phys., 20, 23412351, https://doi.org/10.5194/acp-20-2341-2020, 2020.

Pistone, K., Redemann, J., Doherty, S., Zuidema, P., Burton, S., Cairns, B., Cochrane, S., Ferrare, R., Flynn, C., Freitag, S., Howell, S. G., Kacenelenbogen, M., LeBlanc, S., Liu, X., Schmidt, K. S., Sedlacek III, A. J., Segal-Rozenhaimer, M., Shinozuka, Y., Stamnes, S., van Diedenhoven, B., Van Harten, G., and Xu, F.: Intercomparison of biomass burning aerosol optical properties from in situ and remote-sensing instruments in ORACLES-2016, Atmos. Chem. Phys., 19, 9181-9208, https://doi.org/10.5194/acp-19-9181-2019, 2019.

Pistone, K., Zuidema, P., Wood, R., Diamond, M., da Silva, A. M., Ferrada, G., Saide, P., Ueyama, R., Ryoo, J.-M., Pfister, L., Podolske, J., Noone, D., Bennett, R., Stith, E., Carmichael, G., Redemann, J., Flynn, C., LeBlanc, S., Segal-Rozenhaimer, M., and Shinozuka, Y.: Exploring the elevated water vapor signal associated with the free-tropospheric biomass burning plume over the southeast Atlantic Ocean, Atmos. Chem. Phys. Discuss. [preprint], https://doi.org/10.5194/acp-2020-1322, in review, 2021.

Rajapakshe, C., Zhang, Z., Yorks, J. E., Yu, H., Tan, Q., Meyer, K., Platnick, S., and Winker, D. M.: Seasonally transported aerosol layers over southeast Atlantic are closer to underlying clouds than previously reported, Geophys. Res. Lett., 44, 5818-5825, https://doi.org/10.1002/2017GL073559, 2017.

Redemann, J., Wood, R., Zuidema, P., Doherty, S. J., Luna, B., LeBlanc, S. E., Diamond, M. S., Shinozuka, Y., Chang, I. Y., Ueyama, R., Pfister, L., Ryoo, J.-M., Dobracki, A. N., da Silva, A. M., Longo, K. M., Kacenelenbogen, M. S., Flynn, C. J., Pistone, K., Knox, N. M., Piketh, S. J., Haywood, J. M., Formenti, P., Mallet, M., Stier, P., Ackerman, A. S., Bauer, S. E., Fridlind, A. M., Carmichael, G. R., Saide, P. E., Ferrada, G. A., Howell, S. G., Freitag, S., Cairns, B., Holben, B. N., Knobelspiesse, K. D., Tanelli, S., L'Ecuyer, T. S., Dzambo, A. M., Sy, O. O., McFarquhar, G. M., Poellot, M. R., Gupta, S., O'Brien, J. R., Nenes, A., Kacarab, M., Wong, J. P. S., Small-Griswold, J. D., Thornhill, K. L., Noone, D., Podolske, J. R., Schmidt, K. S., Pilewskie, P., Chen, H., Cochrane, S. P., Sedlacek, A. J., Lang, T. J., Stith, E., Segal-Rozenhaimer, M., Ferrare, R. A., Burton, S. P., Hostetler, C. A., Diner, D. J., Seidel, F. C., Platnick, S. E., Myers, J. S., Meyer, K. G., Spangenberg, D. A., Maring, H., and Gao, L.: An overview of the ORACLES (ObseRvations of Aerosols above CLouds and their intEractionS) project: aerosolcloud-radiation interactions in the southeast Atlantic basin, Atmos. Chem. Phys., 21, 1507-1563, https://doi.org/10.5194/acp21-1507-2021, 2021.

Rosenfeld, D., Andreae, M. O., Asmi, A., Chin, M., de Leeuw, G., Donovan, D., Kahn, R., Kinne, S., Kivekäs, N., Kulmala, M., Lau, W., Schmidt, S., Suni, T., Wagner, T., Wild, M., and Quaas, J.: Global observations of aerosol-cloud precipitation-climate interactions, Rev. Geophys., 52, 750-808, https://doi.org/10.1002/2013RG000441, 2014.
Sakaeda, N., Wood, R., and Rasch, P. J.: Direct and semidirect aerosol effects of southern African biomass burning aerosol, J. Geophys. Res., 116, D12205, https://doi.org/10.1029/2010JD015540, 2011.

Small, J. D., Chuang, P. Y., Feingold, G., and Jiang, H.: Can aerosol decrease cloud lifetime?, Geophys. Res. Lett., 36, 16806, https://doi.org/10.1029/2009GL038888, 2009.

Sorooshian, A., Feingold, G., Lebsock, M. D., Jiang, H., and Stephens, G. L.: On the precipitation susceptibility of clouds to aerosol perturbations, Geophys. Res. Lett., 36, L13803, https://doi.org/10.1029/2009GL038993, 2009.

Stein, A. F., Draxler, R. R., Rolph, G. D., Stunder, B. J. B., Cohen, M. D., and Ngan, F.: NOAA's HYSPLIT Atmospheric Transport and Dispersion Modeling System, B. Am. Meteorol. Soc., 96, 2059-2077, https://doi.org/10.1175/BAMS-D-14$00110.1,2015$.

Stephens, M., Turner, N., and Sandberg, J.: Particle identification by laser-induced incandescence in a solid-state laser cavity, Appl. Optics, 42, 3726-3736, 2003.

Stevens, B. and Feingold, G.: Untangling aerosol effects on clouds and precipitation in a buffered system, Nature, 461, 607-613, https://doi.org/10.1038/nature08281, 2009.

Strapp, J. W., Leaitch, W. R., and Liu, P. S. K.: Hydrated and Dried Aerosol-Size-Distribution Measurements from the Particle Measuring Systems FSSP-300 Probe and the Deiced PCASP-100x Probe, J. Atmos. Ocean. Tech., 9, 548-555, 1992.

Stubenrauch, C. J., Rossow, W. B., Kinne, S., Ackerman, S., Cesana, G., Chepfer, H., Di Girolamo, L., Getzewich, B., Guignard, A., Heidinger, A., Maddux, B. C., Menzel, W. P., Minnis, P., Pearl, C., Platnick, S., Poulsen, C., Riedi, J., Sun-Mack, S., Walther, A., Winker, D., Zeng, S., and Zhao, G.: Assessments of Global Cloud Datasets from Satellites: Project and Database initiated by the GEWEX Radiation Panel, B. Am. Meteorol. Soc., 94, 1031-1049, 2013.

Twomey, S.: Pollution and the Planetary Albedo, Atmos. Environ., 8, 1251-1256, 1974.

Twomey, S.: The influence of pollution on the shortwave albedo of clouds, J. Atmos. Sci., 34, 1149-1152, 1977.

Twomey, S.: Aerosols, clouds and radiation, Atmos. Environ., 25A, 2435-2442, 1991.

van der Werf, G. R., Randerson, J. T., Giglio, L., Collatz, G. J., Mu, M., Kasibhatla, P. S., Morton, D. C., DeFries, R. S., Jin, Y., and van Leeuwen, T. T.: Global fire emissions and the contribution of deforestation, savanna, forest, agricultural, and peat fires (1997-2009), Atmos. Chem. Phys., 10, 11707-11735, https://doi.org/10.5194/acp-10-11707-2010, 2010.

Wang, $\mathrm{H}$. and $\mathrm{Su}, \mathrm{W}$.: Evaluating and understanding top of the atmosphere cloud radiative effects in Intergovernmental Panel on Climate Change (IPCC) Fifth Assessment Report (AR5) Coupled Model Intercomparison Project Phase 5 (CMIP5) models using satellite observations, J. Geophys. Res., 118, 683-699, https://doi.org/10.1029/2012JD018619, 2013.

Wang, Y., McFarquhar, G. M., Rauber, R. M., Zhao, C., Wu, W., Finlon, J. A., Stechman, D. M., Stith, J., Jensen, J. B., Schnaiter, M., J?rvinen, E., Waitz, F., Vivekanandan, J., Dixon, M., Rainwater, B., and Toohey, D. W.: Microphysical properties of generating cells over the Southern Ocean: Results from SOCRATES, J. Geophys. Res., 125, e2019JD032237, https://doi.org/10.1029/2019JD032237, 2020. 
Wilcox, E. M.: Stratocumulus cloud thickening beneath layers of absorbing smoke aerosol, Atmos. Chem. Phys., 10, 1176911777, https://doi.org/10.5194/acp-10-11769-2010, 2010.

Wood, R.: Stratocumulus Clouds, Mon. Weather Rev., 140, 2373 2423, https://doi.org/10.1175/MWR-D-11-00121.1, 2012.

Yamaguchi, T., Feingold, G., Kazil, J., and McComiskey, A.: Stratocumulus to cumulus transition in the presence of elevated smoke layers, Geophys. Res. Lett., 42, 10478-10485, https://doi.org/10.1002/2015GL066544, 2015.

Zhou, X., Ackerman, A. S., Fridlind, A. M., Wood, R., and Kollias, P.: Impacts of solar-absorbing aerosol layers on the transition of stratocumulus to trade cumulus clouds, Atmos. Chem. Phys., 17, 12725-12742, https://doi.org/10.5194/acp-17-127252017, 2017.
Zuidema, P., Redemann, J., Haywood, J., Wood, R., Piketh, S., Hipondoka, M., and Formenti, P.: Smoke and Clouds above the Southeast Atlantic: Upcoming Field Campaigns Probe Absorbing Aerosol's Impact on Climate, B. Am. Meteorol. Soc., 97, 1131-1135, https://doi.org/10.1175/BAMS-D-15-00082.1, 2016. 